\title{
Integrative redescription of Hypsibius pallidoides Pilato et al., 2011 (Eutardigrada: Hypsibioidea) with the erection of a new genus and discussion on the phylogeny of Hypsibiidae
}

\author{
Denis V. TUMANOV ${ }^{1,2}$ \\ ${ }^{1}$ Department of Invertebrate Zoology, Faculty of Biology, Saint-Petersburg State University, 199034, \\ Universitetskaya nab. 7/9, Saint Petersburg, Russia. \\ ${ }^{2}$ The Laboratory of the Marine Research, Zoological Institute of Russian Academy of Sciences, \\ 199034, Universitetskaja nab. 1, Saint Petersburg, Russia. \\ Email: d.tumanov@spbu.ru
}

urn:1sid:zoobank.org:author:49E22A70-C27B-485B-941E-577666EE65F9

\begin{abstract}
An integrative redescription of Hypsibius pallidoides Pilato, Kiosya, Lisi, Inshina \& Biserov, 2011 was undertaken following a reexamination of the type material and new material using highquality light microscopy, scanning electron microscopy and methods of molecular taxonomy. Detailed morphological investigations revealed a unique complex of characters that precluded the attribution of this species to the genus Hypsibius Ehrenberg, 1848. Furthermore, phylogenetic analyses indicated the affinity of this species within the subfamily Pilatobiinae (Hypsibiidae). Notahypsibius gen. nov. is erected for H. pallidoides and two putatively related species: H. scaber Maucci, 1987 and Ramazzottius arcticus (Murray, 1907). An emended diagnosis for the genus Pilatobius is given, while the subfamily Pilatobiinae lacks a cohesive morphological diagnosis despite representing, at the same time, a wellsupported molecular clade. Obvious controversy between the results of the morphological and molecular analyses of the phylogeny of Hypsibioidea is discussed. The distribution of morphological characters such as the claw type, organization of the bucco-pharyngeal apparatus, and egg shell sculpture type within Eutardigrada is analyzed and their phylogenetic significance discussed.
\end{abstract}

Keywords. Tardigrada, morphology, trait evolution, Pilatobiinae, molecular taxonomy.

Tumanov D.V. 2020. Integrative redescription of Hypsibius pallidoides Pilato et al., 2011 (Eutardigrada: Hypsibioidea) with the erection of a new genus and discussion on the phylogeny of Hypsibiidae. European Journal of Taxonomy 681: 1-37. https://doi.org/10.5852/ejt.2020.681

\section{Introduction}

Phylum Tardigrada Doyère, 1840 is a group of widely distributed microscopical multicellular animals. Currently there are ca 1300 known species (Degma et al. 2019), but this is very likely an underrepresentation of the actual number of taxa, as the global diversity of tardigrades is considered poorly investigated (Bartels et al. 2016). Along with the description of new taxa, the redescription of known species using the integrative approach, i.e., combining a morphological analysis with methods of molecular taxonomy and phylogeny, is a promising way to improve our understanding of the real 
taxonomical richness of this group (Bertolani et al. 2011a; Gąsiorek et al. 2016, 2018; Kaczmarek et al. 2018; Stec et al. 2018; Guidetti et al. 2019a). Molecular methods can also help to infer phylogenetic relationships within Tardigrada when a morphological analysis alone is insufficient due to the paucity of the morphological variation and the prevalence of evolutionary parallelism in taxonomically important structures (Kiehl et al. 2007; Sands et al. 2008; Bertolani et al. 2014; Cesari et al. 2016; Guil et al. 2019; Gąsiorek et al. 2019a, 2019b, 2019c).

Hypsibius Ehrenberg, 1848 is the type genus, and, with 40 described species (Degma et al. 2019, with corrections according to Dastych 2019), also the largest genus of the family Hypsibiidae Pilato, 1969. Intrageneric morphological heterogeneity and phylogenetic clues both suggest a polyphyletic nature of this taxon (Guil \& Giribet 2012; Gąsiorek et al. 2018). However, a molecular phylogenetic analysis of most of the morphologically divergent forms previously revealed within the genus Hypsybius sensu lato (i.e., genera Borealibius Pilato, Guidetti, Rebecchi, Lisi, Hansen \& Bertolani, 2006, Cryobiotus Dastych, 2019, and complex of species similar to H. scabropygus Cuénot, 1929) demonstrated their close affinity to the 'typical' species of Hypsibius, so the subfamily Hypsibiinae Pilato, 1969 seems to be monophyletic (Bertolani et al. 2014; Gąsiorek et al. 2018). Previously, only the genera Acutuncus Pilato \& Binda, 1997 and Mixibius Pilato, 1992, both separated from the genus Hypsibius on the base of a morphological analysis (Pilato \& Binda 1997; Pilato 1992), were demonstrated as lineages phylogenetically distant from the subfamily Hypsibiinae (Kiehl et al. 2007; Sands et al. 2008; Marley et al. 2011).

In 2016, I found a single adult tardigrade specimen and an exuvium containing eggs from a moss sample collected in St Petersburg, Russia, and an additional adult specimen from a moss sample collected in Golubinjak Forest Park, Croatia. I attributed both specimens preliminarily to the species Hypsibius pallidoides Pilato, Kiosya, Lisi, Inshina \& Biserov, 2011, which was described based on hypsibiid individuals from Kherson Oblast, South Ukraine (Pilato et al. 2011). In 2018, I obtained numerous specimens of $H$. pallidoides from moss collected in Carinthia, Austria. This finding made it possible to establish a laboratory culture of the species to be used for morphological and molecular analyses. I also reviewed some specimens in my collection that had previously been identified as Hypsibius pallidus Thulin, 1911 and found that these were actually attributable to H. pallidoides.

The initial investigations of the above mentioned material of $H$. pallidoides revealed some subtle differences to the original species description. This necessitated an examination of the type series. During my visit to Catania in August 2019, I had the opportunity to compare my specimens with the holotype and paratypes of $H$. pallidoides in the Binda and Pilato collection (Museum of the Department of Animal Biology "Marcello La Greca", University of Catania, Italy). Further comparisons were made with paratypes obtained from Y. Kiosya (Kharkiv, Ukraine). Studies of the type material and additional specimens revealed some inaccuracies in the original description of $H$. pallidoides. In this paper, I give a redescription of this species based on the type material and on my own specimens. Scanning Electron Microscopy (SEM) investigation provided an opportunity to explore details of the structures of this species which were previously indiscernible with the use of only Light Microscopy (LM). Sequencing and analyses of the phylogenetically significant genes (COI, 18S rRNA, 28S rRNA and ITS-2) led to the clarification of the phylogenetic position of $H$. pallidoides and to the institution of a new genus.

\section{Material and methods}

\section{Sampling and culturing}

Tardigrades were extracted from rehydrated samples using a standard technique of washing them through two sieves (Tumanov 2018). The content of the fine sieve was examined under a Leica M205C stereo microscope. 
A laboratory culture of $H$. pallidoides was established from several living specimens extracted from a sample collected in Austria. Animals were kept in plastic Petri dishes with a mixture of distilled and filtered tap water (3:1) and Chlorella sp., a unicellular freshwater alga (received from Core Facilities Center "Culture Collection of Microorganisms" of St Petersburg State University). To aid tardigrade locomotion, the Petri dish bottom was scratched with fine sandpaper as recommended by Kosztyła et al. (2016). The culture was maintained at $16^{\circ} \mathrm{C}$.

\section{Microscopy and imaging}

The tardigrades found in moss samples or acquired from the laboratory culture were fixed with acetic acid or relaxed by incubating live individuals at $60^{\circ} \mathrm{C}$ for $30 \mathrm{~min}$ (Morek et al. 2016) and mounted on slides in Hoyer's medium. Permanent slides were examined under a Leica DM2500 microscope equipped with phase contrast (PhC) and differential interference contrast (DIC). Photographs were made using a Nikon DS-Fi3 digital camera with NIS software.

For scanning electron microscopy (SEM) specimens were thermally relaxed at $60^{\circ} \mathrm{C}$ (Morek et al. 2016), dehydrated in an ascending ethyl alcohol series $(10 \%, 20 \%, 30 \%, 50 \%, 70 \%, 96 \%)$ and acetone, critical-point dried in $\mathrm{CO}_{2}$, mounted on stubs and coated with gold. The bucco-pharyngeal apparatus was prepared for SEM investigation following the protocol of Eibye-Jacobsen (2001) as modified by Gąsiorek et al. (2016). A Tescan MIRA3 LMU Scanning Electron Microscope was used for observations (Centre for Molecular and Cell Technologies, St Petersburg State University).

\section{Morphometrics}

The sample size for morphometrics was chosen following the recommendations of Stec et al. (2016a). All measurements are given in micrometres $(\mu \mathrm{m})$. Structures were measured only if their orientations were suitable. Body length was measured from the anterior end of the body to the posterior end, excluding the hind legs. The bucco-pharyngeal tube was measured from the anterior margin of the stylet sheaths to the caudal end of the buccal tube, not including the buccal apophyses. Terminology for the structures within the bucco-pharyngeal apparatus and for the claws follows that of Pilato \& Binda (2010). Elements of the buccal apparatus were measured according to Kaczmarek \& Michalczyk (2017). Claws were measured following Beasley et al. (2008), but the total length of the claws was also measured (according to Pilato et al. 2002) to maintain compatibility with the initial description. The $p t$ index used is the percentage ratio between the length of a structure and the length of the buccal tube (Pilato 1981) and is presented here in italics. Morphometric data were handled using ver. 1.6 of the "Parachela" template, which is available from the Tardigrada Register (Michalczyk \& Kaczmarek 2013) with total length of the claws added.

\section{Genotyping}

DNA was extracted from 15 individual animals using QuickExtract ${ }^{\mathrm{TM}}$ DNA Extraction Solution (Lucigen Corporation, USA) using the following protocol (kindly provided by Torbjørn Ekrem, Norwegian University of Science and Technology).

1) Tardigrades were sorted in water and specimens were rinsed individually in $\mathrm{ddH}_{2} \mathrm{O}$.

2) Each individual specimen was transferred by pipette into a PCR-tube containing $70 \mu 1$ QuickExtract ${ }^{\mathrm{TM}}$.

3) PCR-tubes were vortexed well, spun down (5 min at $3500 \mathrm{RPM}$ ), then kept at room temperature $\left(\approx 25^{\circ} \mathrm{C}\right)$ for $2 \mathrm{hrs}$.

4) PCR-tubes were incubated at $65^{\circ} \mathrm{C}$ for $15 \mathrm{~min}$ (in a PCR-machine), vortexed every 5 min and spun down.

5) PCR-tubes were incubated at $98^{\circ} \mathrm{C}$ for $2 \mathrm{~min}$. 
6) $60 \mu \mathrm{l}$ of the extract supernatant were transferred into a new, sterile PCR tube. The supernatant was collected in order to avoid the exoskeleton remaining at the bottom. The PCR-tubes containing extract were then stored at $-20^{\circ} \mathrm{C}$ for later use in PCR.

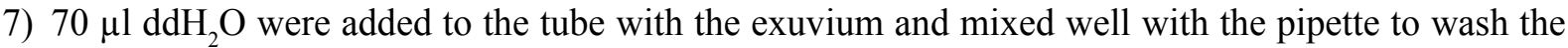
exoskeleton.

8) Water and exoskeleton were transferred to a glass staining block with $\operatorname{ddH}_{2} \mathrm{O}$. The exoskeleton was collected and mounted on a microscope slide in Hoyer's medium and retained as the hologenophore (Pleijel et al. 2008).

Four genes were sequenced: a small ribosome subunit (18S rRNA) gene, a large ribosome subunit (28S rRNA) gene, internal transcribed spacer (ITS-2), and the cytochrome oxidase subunit I (COI) gene. Both 18S rRNA and 28S rRNA are nuclear markers used in phylogenetic analyses to investigate high taxonomic levels (Jørgensen et al. 2010, 2011; Guil \& Giribet 2012; Bertolani et al. 2014; Guil et al. 2019; Gąsiorek et al. 2019b, 2019c). COI is a protein-coding mitochondrial marker that is widely used as a standard barcode gene of intermediate to high effective mutation rate (Bertolani et al. 2011b). ITS-2 is a non-coding nuclear fragment with high evolution rates used for both intra-specific comparisons and comparisons between closely related species (Gąsiorek et al. 2016, 2018; Stec et al. 2018). A complete 18S rRNA gene was amplified in several overlapping fragments using primer pairs: SSU_F_04 and SSU_R_26, 18Sfw and rev960, fw390 and rev18S, 5F and 9R (for primer details see Table 1). These products were sequenced with PCR primers and the internal primers fw1230 and rev1460. A fragment of the 28S rRNA gene was amplified and sequenced using primers 28_F0001 and 28S_R1800. PCR reactions included $2 \mu 1$ template DNA, $1 \mu \mathrm{l}$ of each primer, $1 \mu 1$ DNTP, $5 \mu 1$ Taq Buffer (10X) (-Mg), $4 \mu 125 \mathrm{mM} \mathrm{MgCl}_{2}$ and $0.2 \mu 1$ Taq DNA Polymerase (Thermo Scientific ${ }^{\mathrm{TM}}$ ) in a final volume of $50 \mu 1$. The PCR cycling profile for the $18 \mathrm{~S}$ and $28 \mathrm{~S}$ genes was as follows: initial denaturation at $95^{\circ} \mathrm{C}$ for $5 \mathrm{~min}$, then 35 cycles of $95^{\circ} \mathrm{C}$ for $1 \mathrm{~min}, 50^{\circ} \mathrm{C}$ for $1 \mathrm{~min}, 72^{\circ} \mathrm{C}$ for $2 \mathrm{~min}$, and final elongation at $72^{\circ} \mathrm{C}$ for $10 \mathrm{~min}$. ITS-2 was amplified and sequenced using primers ITS2_Eutar_Ff and ITS2_Eutar_Rr (Stec et al. 2018). The PCR cycling profile for ITS-2 was as follows: initial denaturation at $95^{\circ} \mathrm{C}$ for 3 min, followed by 30 cycles of denaturation at $95^{\circ} \mathrm{C}$ for $1 \mathrm{~min}$, annealing at $55^{\circ} \mathrm{C}$ for $2 \mathrm{~min}$, and elongation at $72^{\circ} \mathrm{C}$ for $2 \mathrm{~min}$, and a final elongation step at $72^{\circ} \mathrm{C}$ lasting $10 \mathrm{~min}$. A fragment of the COI mtDNA gene was amplified and sequenced using primers LCO1490 and HCO2198 (Folmer et al. 1994). The PCR cycling profile for the COI gene was as follows: initial denaturation at $94^{\circ} \mathrm{C}$ for $5 \mathrm{~min}$, followed by five cycles of denaturation $1 \mathrm{~min}$ at $94^{\circ} \mathrm{C}$, annealing at $42^{\circ} \mathrm{C}$ for $1.5 \mathrm{~min}$ and amplification at $72^{\circ} \mathrm{C}$ for $1.5 \mathrm{~min}$; then 35 cycles of $94^{\circ} \mathrm{C}$ for $1 \mathrm{~min}, 50^{\circ} \mathrm{C}$ for $1.5 \mathrm{~min}, 72^{\circ} \mathrm{C}$ for $1 \mathrm{~min}$, and final elongation at $72^{\circ} \mathrm{C}$ for $5 \mathrm{~min}$. COI sequences were translated to amino acids by using the invertebrate mitochondrial code implemented in MEGA7 (Kumar et al. 2016) in order to check for the presence of stop codons and therefore of pseudogenes.

PCR products were visualized in 1.5\% agarose gel stained with Ethidium bromide. All amplicons were sequenced directly using ABI PRISM Big Dye Terminator Cycle Sequencing Kit (Applied Biosystems, Foster City, CA, USA) on ABI Prism 310 Genetic Analyzer. Sequences were edited and assembled using ChromasPro software (Technelysium, USA).

\section{Phylogenetic analyses}

All sequences of Hypsibioidea Guil, Jørgensen \& Kristensen, 2019 of appropriate length available in GenBank at the time of the analysis were downloaded and those originating from published works with reliable attribution of the investigated taxa were selected (see Supplementary file SM.01). Because of the low number of species of Hypsibioidea where both $18 \mathrm{~S}$ and $28 \mathrm{~S}$ sequences are available, these genes were analysed separately, also the analysis of concatenated $18 \mathrm{~S}+28 \mathrm{~S}$ sequences alignment was performed. Four species of Macrobiotus C.A.S. Schultze, 1834 (Macrobiotoidea Guil, Jørgensen \& Kristensen, 2019) were used as outgroup. First, sequences were automatically aligned using the Muscle 
Table 1. Primers used for amplification of the four DNA fragments sequenced in the study.

\begin{tabular}{lllll}
\hline DNA fragment & Primer name & Primer direction & Primer sequence (5'-3') & Primer source \\
\hline 18S rRNA & SSU_F_04 & forward & GCTTGTCTCAAAGATTAAGCC & Kiehl et al. 2007 \\
& SSU_R_26 & reverse & CGAAAGCATTTGCCAAGAATG & Kiehl et al. 2007 \\
& 18Sfw & forward & CTTGTCTCAAAGATTAAGCCATGCA & Dabert et al. 2014 \\
& rev960 & reverse & GACGGTCCAAGAATTTCAC & Dabert et al. 2014 \\
& fw390 & forward & AATCAGGGTTCGATTCCGGAGA & Dabert et al. 2014 \\
& rew18S & reverse & TGATCCTTCCGCAGGTTCACCT & Dabert et al. 2014 \\
& 5F & forward & GCGAAAGCATTTGCCAAGAA & Giribet et al. 1996 \\
& $9 \mathrm{R}$ & reverse & GATCCTTCCGCAGGTTCACCTAC & Giribet et al. 1996 \\
& fw1230 & forward & TGAAACTTAAAGGAATTGACG & Dabert et al. 2014 \\
& rev1460 & reverse & CATCACAGACCTGTTATTGC & Dabert et al. 2014 \\
& 28SF0001 & forward & ACCCVCYNAATTTAAGCATAT & Dabert et al. 2014 \\
& 28SR1800 & reverse & GTTCACATGGAACCCTTCT & Dabert et al. 2014 \\
& LCO1490 & forward & GGTCAACAAATCATAAAGATATTGG & Folmer et al. 1994 \\
& HCO2198 & reverse & TAAACTTCAGGGTGACCAAAAAATCA & Folmer et al. 1994 \\
& ITS2_Eutar_Ff & forward & CGTAACGTGAATTGCAGGAC & Stec et al. 2018 \\
& ITS2_Eutar_Rr & reverse & TGATATGCTTAAGTTCAGCGG & Stec et al. 2018 \\
\hline
\end{tabular}

algorithm (Edgar 2004) as implemented in SeaView 4.0 (Gouy et al. 2010); the alignment was later refined manually. Final align lengths were $1685 \mathrm{bp}$ for $18 \mathrm{~S}$ gene and $2207 \mathrm{bp}$ for $28 \mathrm{~S}$ gene. Best fitting model evaluations for each analysis were performed using jModeltest 2.1.10 (Darriba et al. 2012) resulting in the GTR + Gamma+I model to be most suitable for all the datasets.

Maximum-likelihood (ML) topologies were constructed using the RaxML 8.2.10 program (Stamatakis 2014) with GTR $+\gamma+$ I model; the number of invariant sites, alpha parameter and tree topology were optimized by RAxML, 1000 bootstrap pseudoreplicates were used. Bayesian analysis of the same datasets was performed using MrBayes ver. 3.2.6, GTR model with gamma correction for intersite rate variation (8 categories) and the covarion model (Ronquist $\&$ Huelsenbeck 2003). The analyses were run as two separate chains (default heating parameters) for 10 million generations, by which time they had ceased converging (final average standard deviation of the split frequencies was less than 0.01). The quality of chains was estimated using built-in MrBayes tools. jModeltest, RaxML and MrBayes programs were run at the Cipres ver. 3.3 web-site (Miller et al. 2010). Uncorrected pairwise distances were calculated using MEGA7 (Kumar et al. 2016) with gaps/missing data treatment set to "complete deletion".

\section{Institutional acronyms}

Specimens from the following institutions and collections were examined (curator in parenthesis). 
KNU = V.N. Karazin Kharkiv National University, Ukraine, School of Biology (Yevgen Kiosya)

MCVR = Museo Civico di Storia Naturale, Verona, Italy (Roberta Salmaso)

$\mathrm{SPbU}=\mathrm{St}$ Petersburg University, Russia, Faculty of Biology, Department of Invertebrate Zoology (Denis Tumanov)

UNICT = Università degli Studi di Catania, Italy, Museum of the Department of Animal Biology "Marcello La Greca", Binda and Pilato collection (Giovanni Pilato)

\section{Results}

\section{Redescription of Hypsibius pallidoides}

Phylum Tardigrada Doyère, 1840

Class Eutardigrada Richters, 1926

Order Hypsibioidea Guil, Jørgensen \& Kristensen, 2019

Family Hypsibiidae Pilato, 1969

Hypsibius pallidoides Pilato, Kiosya, Lisi, Inshina \& Biserov, 2011

Figs 1-7

\section{Material examined}

Holotype

UKRAINE - Kherson Oblast, Ivano-Rybalchansky district of Chernomorsky biosphere reserve; $46^{\circ} 27^{\prime} 25^{\prime \prime}$ N, 328'56" E; Jun. 2008; D.A. Korolesova leg.; moss on wood; UNICT 5430.

\section{Paratypes}

UKRAINE $\bullet 1$ spec. + 1 exuvium with eggs; same collection data as for holotype; UNICT $5430 \bullet 4$ specs +2 exuviae with eggs; same collection data as for holotype; KNU Чep-9 II.

\section{Other material}

AUSTRIA - 78 specs +35 exuvia with eggs; Carinthia; $46.817818^{\circ} \mathrm{N}, 13.859837^{\circ}$ E; 20 Aug. 2017; A. Smirnov leg.; moss on soil; GenBank: MK973069, MN912103, MK967961 to MK967964, MN927181, MN927182, MN919385, MN915220, MN915221, MK967241, MN918533; SPbU 251(113), 251(28).

CROATIA • 1 spec.; Park Šuma Golubinjak [Golubinjak Forest Park], Primorje-Gorski Kotar County; 45.35216 ${ }^{\circ}$ N, $14.76557^{\circ}$ E; 10 Sep. 2005; O. Orlova leg.; moss on stone; SPbU 228(30).

RUSSIA - St Petersburg • 1 spec. + 1 exuvium; Puskin City; $59.72537^{\circ}$ N, $30.39147^{\circ}$ E; 15 May 2016; D. Tumanov leg.; moss on tree trunk; SPbU 234(10). - Karelia 3 specs +1 exuvium; vicinity of Akkaharju village; $61.49584^{\circ} \mathrm{N}, 29.84775^{\circ} \mathrm{E}$; 11 May 1994; D. Tumanov leg.; mosses and leaf litter from the overgrown lake; SPbU 113(2).

\section{Morphological redescription}

MEAsurements. Body elongated, of uniform width on the entire body length (Fig. 1), with a blunt snout (morphometrics Tables 2-3).

Colour. Body uncoloured or whitish with green gut content. Most specimens with eyespots, usually well-discernible after slide mounting (Fig. 1A) but absent in some specimens.

Cuticular sculptuRe. Dorsal cuticle sculpture consists of a system of transverse folds with smaller irregular folds between (Figs 1B, 2A-D). Cuticle sculpture better visible in the caudal region of the body 
(Figs 2C-D, 3A-B), well developed even in juveniles (Fig. 4E). Ventral surface with poorly developed foldings, visible in SEM only (Fig. 1C).

CEPHALIC SENSORY STRUCTURES. Cephalic body portion with a pair of elliptical sensory organs developed in the form of flat porous areas, separated from the body surface with a oval cuticular groove. These structures are scarcely visible in LM, but are well-discernible in SEM (Fig. 3C-D, black arrowheads). Two indistinctly demarcated porous areas are also developed in the fronto-lateral region of the head, on the each side of the mouth opening (visible in SEM only; Fig. 4A-B, white arrowheads). Central concavity on the dorsal surface of the head (Fig. 3C, white arrowhead) seems to be similar to the structures present in some Isohypsibioidea (see Gąsiorek et al. (2019c: 91, fig. 4b, d) and in Cryobiotus roswithae (Dastych 2019).

MоuтH. Opening antero-ventral, surrounded by six peribuccal lobes (visible in SEM only; Fig. 4C). In large specimens a line of elliptical structures is visible in LM around the mouth opening (Fig. 4G-H, black arrowheads), similar to those described for Acutuncus antarcticus (Richters, 1904) and Hypsibius murrayi (Richters, 1907) (Dastych 1991, 2018). These structures are possibly the compressed peribuccal lobes.

Bucco-Pharyngeal apparatus. Hypsibiinae model sensu Pilato \& Binda 2010 (Fig. 4F). Oral cavity armature with a ring of small teeth located it its anterior part followed by the second band of larger,
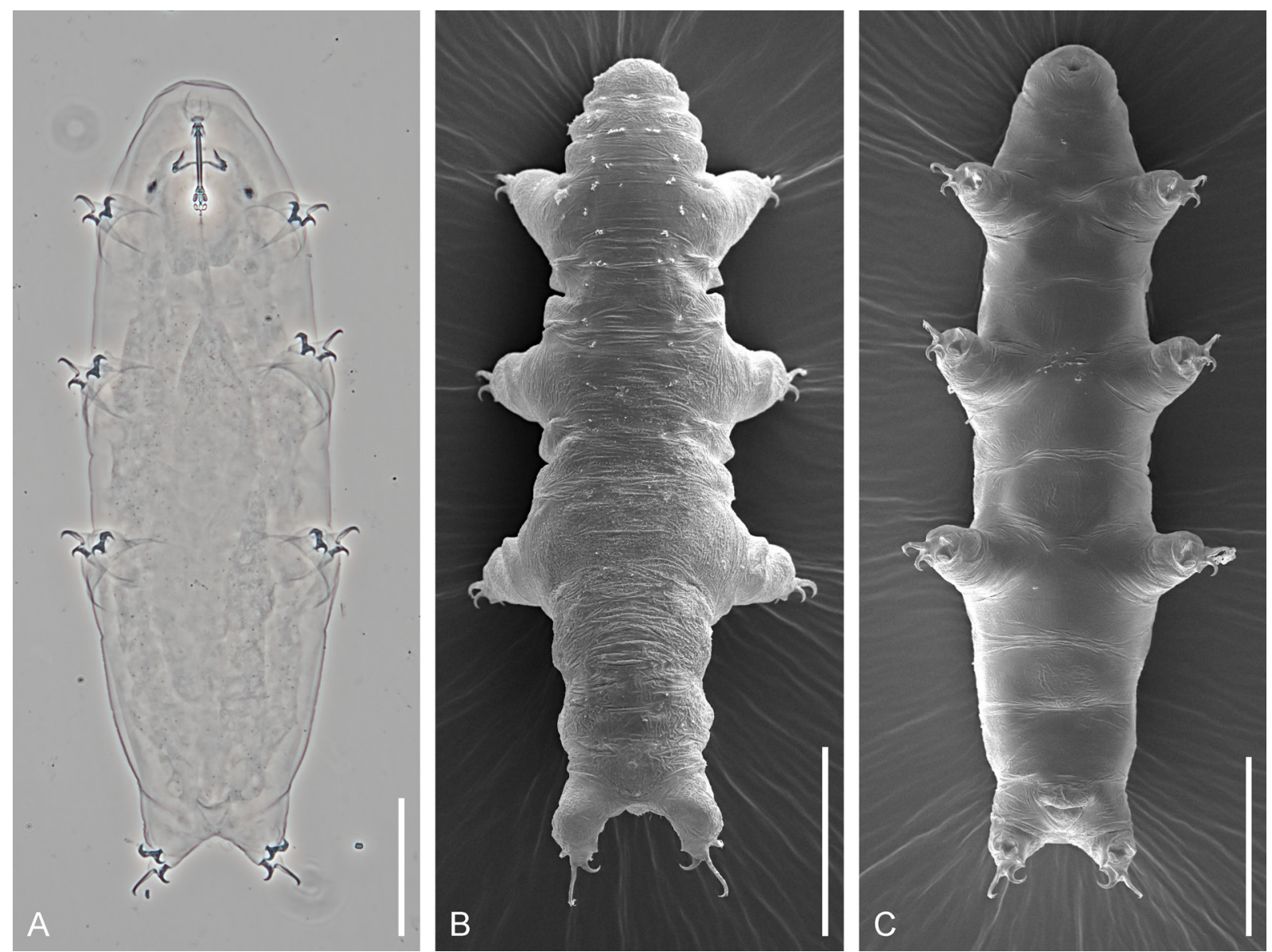

Fig. 1. Hypsibius pallidoides Pilato, Kiosya, Lisi, Inshina \& Biserov, 2011, total view. A. Phase contrast (SPbU 251(82)). B. Dorsal view in SEM. C. Ventral view in SEM. Scale bars $=50 \mu \mathrm{m}$. 
irregular teeth (visible in SEM only; Fig. 4D). Dorsal and ventral apophyses for the insertion of the stylet muscles (AISM) are evidently dissimilar. Dorsal AISM are shorter and higher than ventral, with thickened anterior margin (Fig. 5A-C). A short thickening of the buccal tube wall is present posteriorly to both these apophyses (the ventral poorly visible; Fig. 5A, black arrowheads). Buccal tube rigid, bent ventrally in its caudal part (Fig. 5A). Stylet furcae typically shaped (sensu Pilato \& Binda 2010) (Fig. 4F). Pharyngeal bulb spherical (Fig. 5D, black arrowhead), with well-developed apophyses, two elongated macroplacoids, and a small dot-like structure interpreted here as a septulum (following Pilato et al. 2011) (Fig. 5A, white arrow), connected to the second macroplacoid with a thin cuticular line (often scarcely visible) (Fig. 5D, black arrow). No microplacoids. Posteriorly to the septulum, an indistinct thickening of the cuticular lining similar to "pseudoseptulum" described in Diphascon mirabilis Dastych, 1984 and Hypsibius iskandarovi Tumanov, 1997 is present (Dastych 1984; Tumanov 1997) (Fig. 5D, white arrowhead). First macroplacoid longer than second with a slight constriction in the middle (Fig. 5E-F, black arrowhead). Second macroplacoid can also have a poorly developed subterminal constriction (visible in SEM only) (Fig. 5F, black arrow).
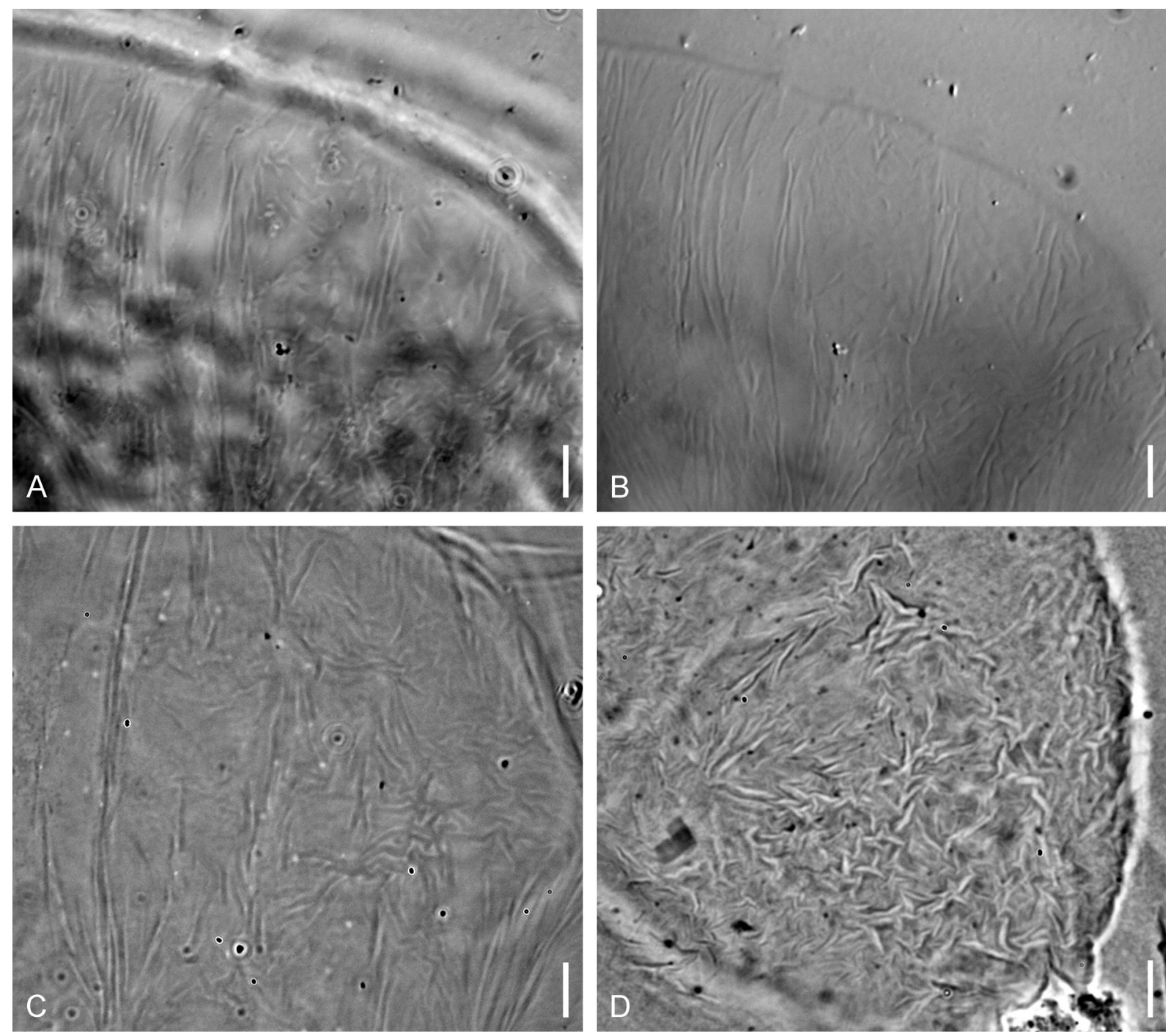

Fig. 2. Hypsibius pallidoides Pilato, Kiosya, Lisi, Inshina \& Biserov, 2011, dorsal sculpture. A. Type series specimen (KNU Чep-9 II), PhC. B. Type series specimen (KNU Чеp-9 II), DIC. C. Specimen from Austria (SPbU 251(82)), PhC. D. Specimen from Russia (SPbU 113(3)). Scale bars $=5 \mu \mathrm{m}$. 

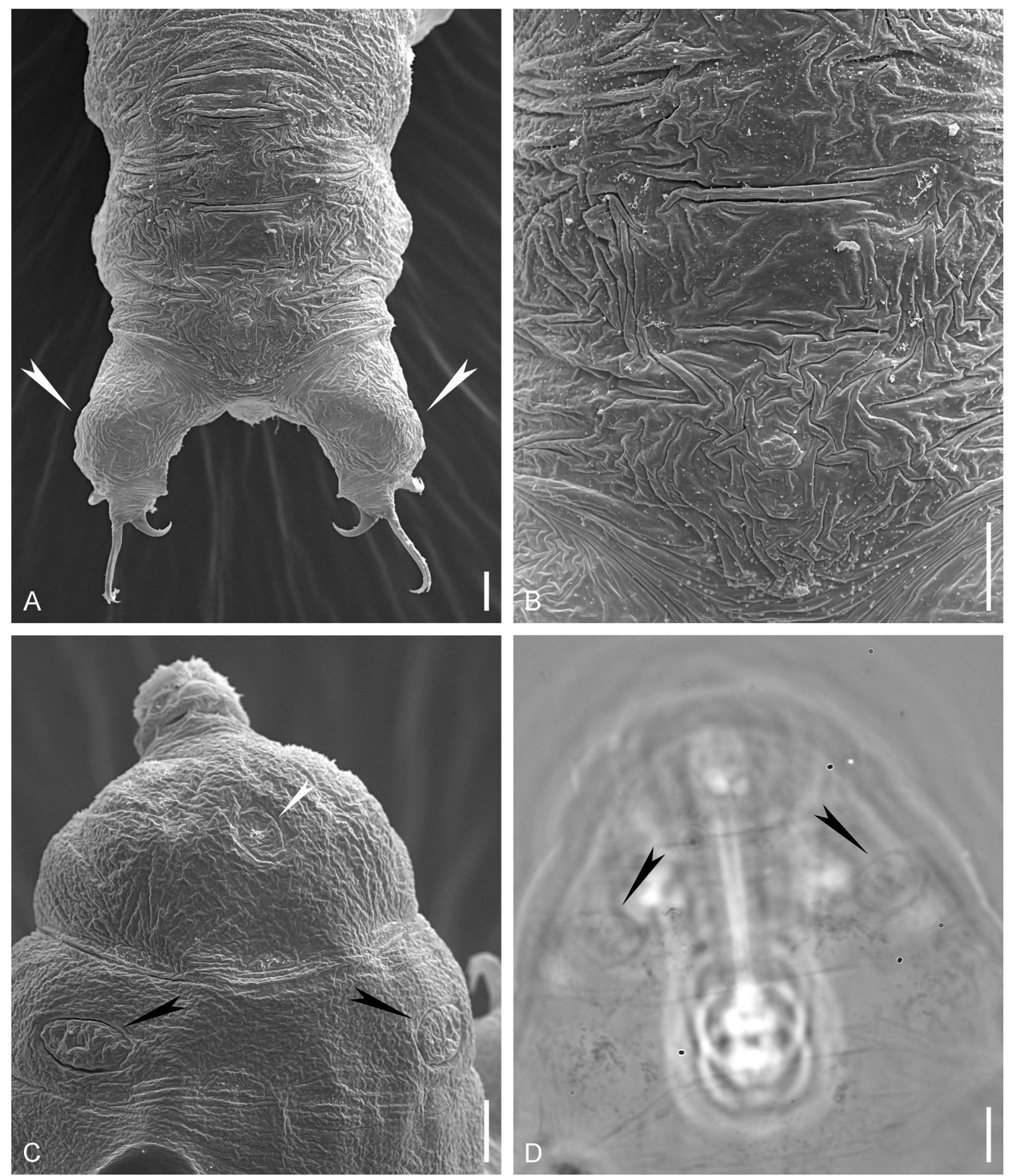

Fig. 3. Hypsibius pallidoides Pilato, Kiosya, Lisi, Inshina \& Biserov, 2011. A. Dorsal view of the caudal body end, white arrowheads indicate the dorsal inflations of the hind legs, SEM. B. Dorsal sculpture of the caudal body region, SEM. C. Dorsal surface of the head region, black arrowheads indicate the elliptical sensory organs, white arrowhead indicates the central concavity on the dorsal surface of the head, SEM. D. Dorsal surface of the head region, black arrowheads indicate the elliptical sensory organs $(\mathrm{SPbU} 251(89)), \mathrm{PhC}$. Scale bars $=5 \mu \mathrm{m}$. 
Table 2 (continued on the next page). Summary of morphometric data for Hypsibius pallidoides Pilato, Kiosya, Lisi, Inshina \& Biserov, 2011 (type series specimens $(\mathrm{n}=4)$ and additional specimens from Croatia and Russia). Measurements are given in $\mu \mathrm{m}, p t$ values in \% (the $p t$ index is the percentage ratio between the length of a structure and the length of the buccal tube).

\begin{tabular}{|c|c|c|c|c|c|c|c|c|c|c|c|c|c|c|}
\hline \multirow[b]{2}{*}{ CHARACTER } & \multicolumn{2}{|c|}{ type series 1} & \multicolumn{2}{|c|}{ type series 2} & \multicolumn{2}{|c|}{ type series 3} & \multicolumn{2}{|c|}{ type series 4} & \multicolumn{2}{|c|}{ Croatia } & \multicolumn{2}{|c|}{ Russia 1} & \multicolumn{2}{|c|}{ Russia 2} \\
\hline & $\mu \mathbf{m}$ & $p t$ & $\mu \mathrm{m}$ & $p t$ & $\mu \mathbf{m}$ & $p t$ & $\mu \mathrm{m}$ & $p t$ & $\mu \mathrm{m}$ & $p t$ & $\mu \mathrm{m}$ & $p t$ & $\mu \mathrm{m}$ & $p t$ \\
\hline Body length & 258 & 985 & 235 & 957 & 201 & 951 & & & 220 & 895 & 288 & 1194 & 247 & 1030 \\
\hline \multicolumn{15}{|l|}{ Buccopharyngeal tube } \\
\hline Buccal tube length & 26.1 & - & 24.6 & - & 21.2 & - & 26.4 & - & 24.5 & - & 24.1 & - & 24.0 & - \\
\hline Stylet support insertion point & 14.7 & 56.2 & 14.3 & 58.0 & 12.2 & 57.6 & 15.5 & 58.6 & 14.7 & 59.8 & 13.7 & 56.8 & 14.0 & 58.4 \\
\hline Buccal tube external width & 1.8 & 6.9 & 1.8 & 7.2 & 1.5 & 7.1 & 1.9 & 7.1 & 1.8 & 7.3 & 2.0 & 8.4 & 1.7 & 7.1 \\
\hline Buccal tube internal width & 1.0 & 3.7 & 0.8 & 3.4 & 0.6 & 2.8 & 0.9 & 3.4 & 0.9 & 3.5 & 1.1 & 4.4 & 0.7 & 3.1 \\
\hline \multicolumn{15}{|l|}{ Placoid lengths } \\
\hline Macroplacoid 1 & 3.5 & 13.3 & 2.9 & 11.8 & 2.2 & 10.6 & 3.1 & 11.6 & 2.5 & 10.2 & 3.4 & 14.0 & 2.5 & 10.5 \\
\hline Macroplacoid 2 & 2.3 & 8.9 & 2.1 & 8.6 & 2.0 & 9.2 & 2.3 & 8.6 & 2.2 & 9.1 & 2.6 & 10.7 & 2.3 & 9.5 \\
\hline Macroplacoid row & 6.6 & 25.1 & 5.7 & 23.2 & 4.7 & 22.1 & 6.2 & 23.6 & 5.6 & 22.9 & 6.5 & 26.8 & 5.8 & 24.2 \\
\hline Placoid row & 8.8 & 33.7 & 8.0 & 32.6 & 6.6 & 31.0 & 8.5 & 32.0 & 7.7 & 31.4 & 8.8 & 36.2 & 8.2 & 34.1 \\
\hline \multicolumn{15}{|l|}{ Claw 1 heights } \\
\hline External base & - & - & 4.6 & 18.5 & 3.2 & 15.2 & 4.6 & 17.4 & 3.9 & 15.9 & 4.4 & 18.0 & 4.3 & 18.0 \\
\hline External primary branch & 8.6 & 33.0 & 8.9 & 36.2 & 6.9 & 32.6 & 8.1 & 30.7 & 7.8 & 31.8 & 9.4 & 38.9 & 7.8 & 32.4 \\
\hline External secondary branch & 4.5 & 17.3 & 4.2 & 17.1 & 4.1 & 19.5 & 5.0 & 19.1 & 4.4 & 18.0 & 4.3 & 17.8 & 4.6 & 19.0 \\
\hline External total & 12.9 & 49.2 & 13.1 & 53.3 & - & - & 12.6 & 47.9 & 12.0 & 48.8 & 14.1 & 58.5 & 11.9 & 49.4 \\
\hline Internal base & 3.6 & 13.9 & 3.9 & 16.0 & & - & 3.4 & 12.7 & - & - & 4.4 & 18.1 & 3.5 & 14.4 \\
\hline Internal primary branch & 4.7 & 18.1 & 5.7 & 23.0 & - & - & 5.1 & 19.2 & - & - & 4.9 & 20.1 & 4.7 & 19.7 \\
\hline Internal secondary branch & 3.2 & 12.2 & & & - & - & 3.4 & 12.7 & - & - & 3.8 & 15.7 & 3.4 & 14.0 \\
\hline Internal total & 8.7 & 33.1 & 8.8 & 35.6 & - & - & 8.4 & 31.7 & - & - & 8.3 & 34.2 & 7.8 & 32.4 \\
\hline \multicolumn{15}{|l|}{ Claw 2 heights } \\
\hline External base & 5.1 & 19.5 & 5.6 & 23.0 & 3.4 & 15.9 & 4.5 & 16.9 & 4.2 & 17.0 & 5.1 & 21.2 & 4.9 & 20.5 \\
\hline External primary branch & 8.9 & 34.1 & 9.8 & 40.0 & 7.7 & 36.3 & 8.5 & 32.0 & 7.7 & 31.6 & 9.8 & 40.4 & 8.6 & 35.7 \\
\hline External secondary branch & 4.7 & 17.9 & 5.4 & 22.0 & 3.7 & 17.7 & 4.9 & 18.5 & 4.4 & 18.0 & 4.5 & 18.8 & 4.7 & 19.5 \\
\hline External total & 12.8 & 48.9 & 15.4 & 62.8 & - & - & 12.9 & 48.9 & 12.2 & 49.8 & 15.4 & 63.6 & 13.3 & 55.4 \\
\hline Internal base & 4.8 & 18.2 & - & - & - & - & 4.1 & 15.6 & 3.7 & 15.0 & 4.5 & 18.8 & 4.3 & 17.7 \\
\hline Internal primary branch & 4.2 & 16.0 & - & - & - & - & 4.7 & 17.9 & 4.4 & 17.9 & 5.7 & 23.7 & 4.5 & 18.7 \\
\hline Internal secondary branch & - & - & - & - & - & - & 4.1 & 15.6 & 3.5 & 14.4 & 4.2 & 17.5 & 3.6 & 14.9 \\
\hline Internal total & - & - & - & - & - & - & 8.5 & 32.3 & 7.9 & 32.2 & 9.3 & 38.4 & 8.2 & 34.0 \\
\hline \multicolumn{15}{|l|}{ Claw 3 heights } \\
\hline External base & 5.0 & 19.2 & 5.3 & 21.6 & 3.1 & 14.5 & 5.3 & 20.1 & 4.7 & 19.0 & 4.7 & 19.3 & 4.9 & 20.2 \\
\hline External primary branch & 8.7 & 33.1 & 9.6 & 39.2 & 7.9 & 37.2 & 8.2 & 31.0 & 7.6 & 30.8 & 9.7 & 40.3 & 8.6 & 35.6 \\
\hline External secondary branch & 4.3 & 16.5 & 5.9 & 24.2 & 3.8 & 17.9 & 4.9 & 18.5 & 4.4 & 17.8 & 5.2 & 21.7 & 4.8 & 20.0 \\
\hline External total & 13.1 & 50.1 & 14.4 & 58.7 & - & - & 13.3 & 50.3 & 12.2 & 49.9 & 14.3 & 59.4 & 13.2 & 54.9 \\
\hline Internal base & 4.2 & 16.0 & - & - & - & - & - & - & - & - & 4.8 & 19.8 & - & - \\
\hline Internal primary branch & - & - & - & - & - & - & - & - & - & - & 4.9 & 20.4 & 5.2 & 21.8 \\
\hline Internal secondary branch & 4.1 & 15.8 & - & - & - & - & - & - & - & - & 4.4 & 18.2 & 3.7 & 15.5 \\
\hline Internal total & - & - & - & - & - & - & 8.5 & 32.1 & - & - & 9.8 & 40.7 & 8.5 & 35.3 \\
\hline \multicolumn{15}{|l|}{ Claw 4 lengths } \\
\hline Anterior base & 4.0 & 15.4 & - & - & - & - & - & - & 3.4 & 14.0 & & & 3.8 & 15.7 \\
\hline Anterior primary branch & 5.4 & 20.6 & - & - & - & - & - & - & 4.8 & 19.6 & 5.8 & 24.0 & 5.4 & 22.4 \\
\hline
\end{tabular}


Table 2 (continued).

\begin{tabular}{|c|c|c|c|c|c|c|c|c|c|c|c|c|c|c|}
\hline \multirow[b]{2}{*}{ CHARACTER } & \multicolumn{2}{|c|}{ type series 1} & \multicolumn{2}{|c|}{ type series 2} & \multicolumn{2}{|c|}{ type series 3} & \multicolumn{2}{|c|}{ type series 4} & \multicolumn{2}{|c|}{ Croatia } & \multicolumn{2}{|c|}{ Russia 1} & \multicolumn{2}{|c|}{ Russia 2} \\
\hline & $\mu \mathrm{m}$ & $p t$ & $\mu \mathbf{m}$ & $p t$ & $\mu \mathbf{m}$ & $p t$ & $\mu \mathrm{m}$ & $p t$ & $\mu \mathbf{m}$ & $p t$ & $\mu \mathbf{m}$ & $p t$ & $\mu \mathrm{m}$ & $p t$ \\
\hline Anterior secondary branch & - & - & - & - & - & - & - & - & 3.5 & 14.3 & 4.9 & 20.2 & 4.8 & 20.0 \\
\hline Anterior total & 9.0 & 34.4 & - & - & - & - & - & - & 8.0 & 32.6 & 10.3 & 42.7 & 9.3 & 38.5 \\
\hline Posterior base & - & - & - & - & - & - & - & - & 4.7 & 19.2 & 5.0 & 20.7 & 5.4 & 22.6 \\
\hline Posterior primary branch & - & - & - & - & - & - & - & - & 10.7 & 43.6 & 11.4 & 47.3 & 12.1 & 50.4 \\
\hline Posterior secondary branch & - & - & - & - & - & - & - & - & 4.7 & 19.3 & 5.8 & 23.9 & 5.9 & 24.6 \\
\hline Posterior total & 13.9 & 53.3 & - & - & 11.1 & 52.5 & - & - & 15.8 & 64.5 & 16.6 & 68.8 & 17.8 & 74.3 \\
\hline
\end{tabular}

LEGS AND CLAws. All legs with well-developed claws, increasing in size from legs I to legs IV (Fig. 6A-I). Legs IV evidently swollen dorsally, above the claws (Fig. 3A, white arrowheads). Claws similar to the Ramazzottius-type claws (sensu Pilato \& Binda 2010 and Guidetti et al. 2019b) with external and internal claws of each leg strongly dissimilar. External claws with massive base + secondary branch complex, where the base is at least as long as the secondary branch and only slightly curved, while the secondary branch is thinner than the base and connected with it at a nearly right angle without forming a smooth ark (Fig. 6A-B, I). Thin and long primary branch connected to the base+secondary branch complex far from the claw's basal point (length of the claw base is equal or slightly exceeds the length of the secondary branch). The connection point is shifted laterally and located near the evident crest developed on the lateral surface of the claw base (Fig. 6G, I, white arrowheads). Basal part of the primary branch flexible, with thinned walls (Fig. 6A-B, black arrowheads). External and posterior claws of $H$. pallidoides differ from typical Ramazzottius-type claws only in having primary branches wider with less pronounced differentiation between rigid distal and soft basal parts. Primary branches are connected with the base by a filamentous structure (not always visible in LM, Fig. 6D, black arrow), but no distinct light-refracting unit is present. Internal claws much shorter than external ones, without flexible parts, with developed internal structure, consisting of the system of cavities and septae (Fig. 6A, D-E). All claws with developed accessory points and widened smooth bases (Fig. 6A-I). Claws of legs I-III with very poorly developed smooth lunules (or pseudolunules, according Gąsiorek et al. 2017) (Fig. 6A, white arrow), usually not discernible on the external claws. Claws of legs IV with welldeveloped wide lunules (Fig. 6E, I). Posterior claws with thickened region on the lunule margin, visible in LM as a dark line, which can create the impression of the presence of a cuticular bar between the bases of the anterior and posterior claws (Fig. 6E-F, black arrows). Legs I-III without cuticular bars near the claw bases, but with an elongated bulge located near the base of the internal claw. In SEM, the pulvinus is similar in appearance to the typical cuticular bar of Hypsibioidea, but in LM no zone of thickened cuticle is visible (Fig. 6C, H, white arrows). Also, poorly developed pulvini are visible on the inner side of the legs (Fig. 6C, H, white asterisks)

EGGS. One to six white subspherical eggs are laid in the exuvium (Fig. 7A), 59.4-71.9 $\mu \mathrm{m}$ in diameter $(65.96 \pm 3.71 ; \mathrm{N}=20)$. Egg shell in LM appears sculptured with minuscule granules, visible only with $\mathrm{PhC}$ or DIC in high magnification (Fig. 7B-C, E-F). In fact, these granules are inner pillar-like structures in the egg shell (Fig. 7D).

\section{DNA sequences}

Sequences of good quality for the 4 aforementioned molecular markers were obtained from five specimens: 2 paragenophores and 3 hologenophores (voucher specimens 251(09), 251(10) and 251(87)). Each gene was represented by single haplotype.

COI sequence (GenBank: MK967241), 688 bp long. 
18S rRNA sequence (GenBank: MN912103), 1777 bp long:

28S rRNA sequence (GenBank: MK967961), 1618 bp long:
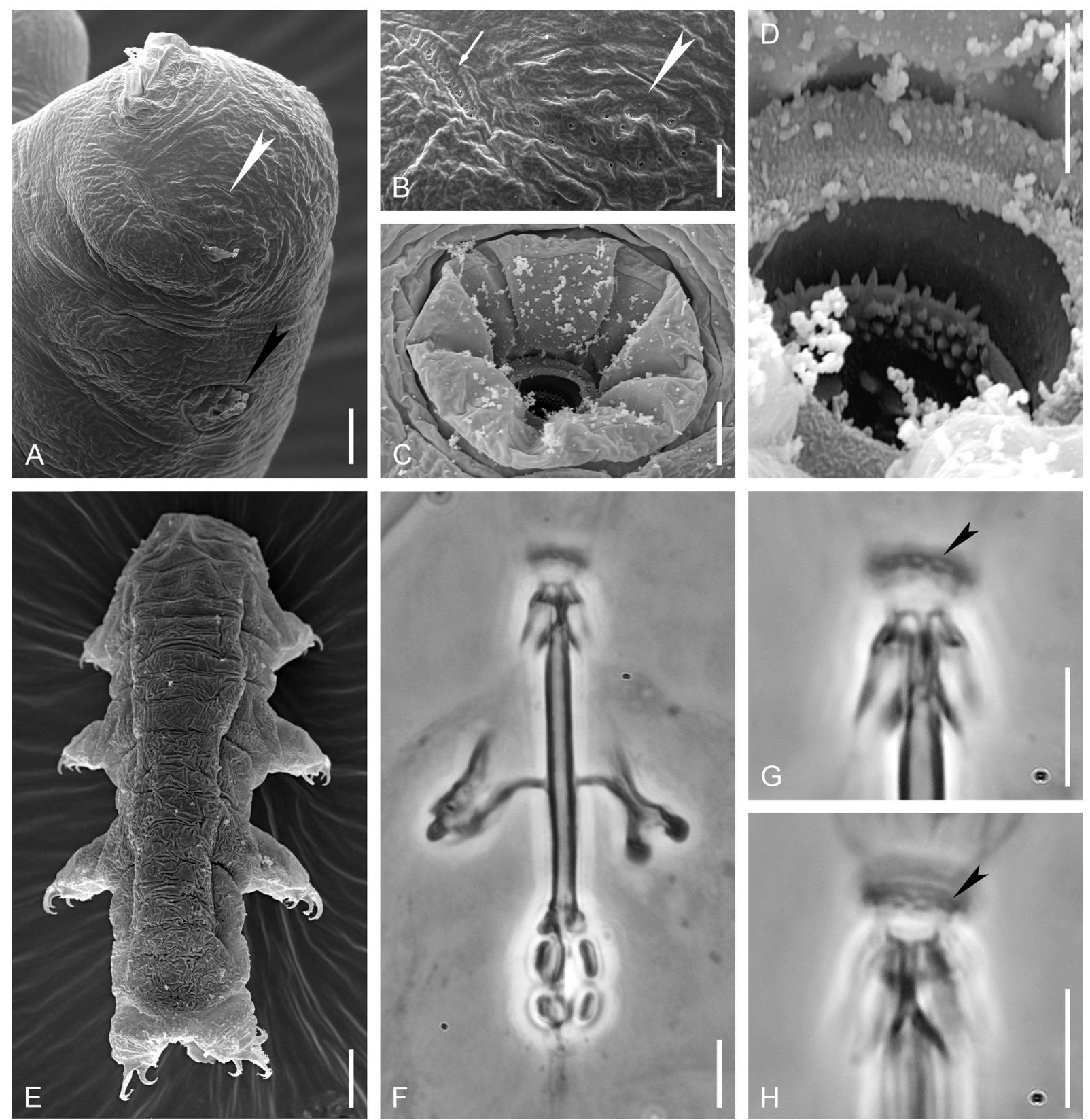

Fig. 4. Hypsibius pallidoides Pilato, Kiosya, Lisi, Inshina \& Biserov, 2011. A. Lateral view of the head region, white arrowhead indicates the anterior porous area, black arrowhead indicates the elliptical sensory organ, SEM. B. Enlarged view of the lateral surface of the head, white arrowhead indicates the anterior porous area, white arrow indicates the muscle attachment zone, SEM. C. Mouth opening with peribuccal lobes, SEM. D. Mouth opening with anterior ring of teeth, SEM. E. Dorsal sculpture of the juvenile, SEM. F. Bucco-pharyngeal apparatus (SPbU 251(82)), PhC. G. Dorsal view of the buccal cavity, black arrowhead indicates the circumoral elliptical structures (SPbU 251(82)), PhC. H. Ventral view of the buccal cavity, black arrowhead indicates the circumoral elliptical structures (SPbU 251(82)), PhC. Scale bars: A, F-H $=5 \mu \mathrm{m} ; \mathrm{B}-\mathrm{C}=2 \mu \mathrm{m} ; \mathrm{D}=1 \mu \mathrm{m} ; \mathrm{E}=10 \mu \mathrm{m}$. 

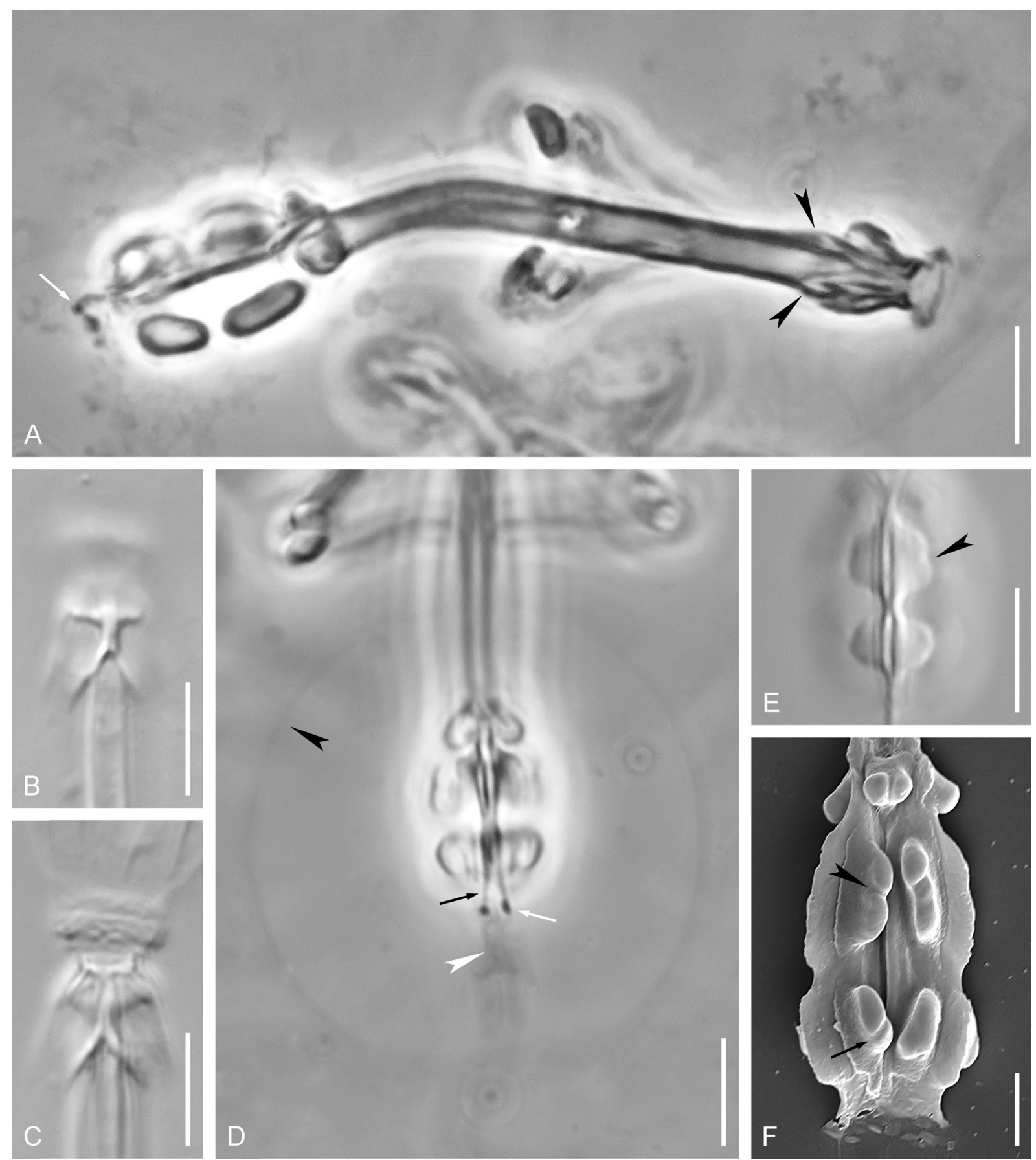

Fig. 5. Hypsibius pallidoides Pilato, Kiosya, Lisi, Inshina \& Biserov, 2011, bucco-pharyngeal apparatus. A. Lateral view of the bucco-pharyngeal apparatus, black arrowheads indicate the thickenings of the buccal tube, white arrow indicates the septulum (SPbU 251(109)), PhC. B. Dorsal AISM (SPbU 251(82)), DIC. C. Ventral AISM (SPbU 251(82)), DIC. D. Pharyngeal bulb, black arrowhead indicates the pharynx outline, black arrow indicates the cuticular line connecting second macroplacoid with septulum, white arrow indicates the septulum, white arrowhead indicates the "pseudoseptulum" (SPbU 251(89)), PhC. E. Macroplacoids, black arrowhead indicates the constriction of the first macroplacoid (SPbU 251(89)), DIC. F. Cuticular structures of the pharynx, black arrowhead indicates the constriction of the first macroplacoid, black arrow indicates the constriction of the second macroplacoid, SEM. Scale bars: $\mathrm{A}-\mathrm{E}=5 \mu \mathrm{m} ; \mathrm{F}=2 \mu \mathrm{m}$. 
Table 3 (continued on the next page). Summary of morphometric data for Hypsibius pallidoides Pilato, Kiosya, Lisi, Inshina \& Biserov, 2011 (Austrian population). Measurements are given in $\mu \mathrm{m}, p t$ values in \% (the $p t$ index is the percentage ratio between the length of a structure and the length of the buccal tube).

\begin{tabular}{|c|c|c|c|c|c|c|c|c|c|c|c|}
\hline \multirow{3}{*}{$\begin{array}{l}\text { CHARACTER } \\
\text { Body length }\end{array}$} & \multirow{3}{*}{$\begin{array}{l}\mathbf{N} \\
30\end{array}$} & \multicolumn{6}{|c|}{ RANGE } & \multicolumn{2}{|c|}{ MEAN } & \multicolumn{2}{|c|}{ SD } \\
\hline & & \multicolumn{3}{|c|}{$\mu \mathrm{m}$} & \multicolumn{3}{|c|}{$p t$} & \multirow{2}{*}{$\begin{array}{c}\mu \mathrm{m} \\
240\end{array}$} & \multirow{2}{*}{$\frac{p t}{1016}$} & \multirow{2}{*}{$\begin{array}{c}\mathbf{\mu m} \\
39\end{array}$} & \multirow{2}{*}{$\frac{p t}{120}$} \\
\hline & & 132 & - & 292 & 695 & - & 1223 & & & & \\
\hline \multicolumn{12}{|l|}{ Buccopharyngeal tube } \\
\hline Buccal tube length & 30 & 19.0 & - & 26.1 & & - & & 23.5 & - & 1.7 & - \\
\hline Stylet support insertion point & 30 & 11.4 & - & 16.2 & 56.9 & - & 63.3 & 14.1 & 60.3 & 1.1 & 1.3 \\
\hline Buccal tube external width & 30 & 1.4 & - & 2.1 & 6.8 & - & 8.6 & 1.8 & 7.8 & 0.2 & 0.4 \\
\hline Buccal tube internal width & 30 & 0.7 & - & 1.3 & 3.2 & - & 5.1 & 1.0 & 4.1 & 0.1 & 0.4 \\
\hline \multicolumn{12}{|l|}{ Placoid lengths } \\
\hline Macroplacoid 1 & 30 & 2.2 & - & 3.8 & 11.2 & - & 15.9 & 3.0 & 12.6 & 0.3 & 0.9 \\
\hline Macroplacoid 2 & 30 & 1.9 & - & 3.2 & 8.7 & - & 13.3 & 2.4 & 10.2 & 0.3 & 0.9 \\
\hline Macroplacoid row & 30 & 4.5 & - & 7.2 & 23.1 & - & 30.0 & 6.0 & 25.7 & 0.6 & 1.3 \\
\hline Placoid row & 30 & 5.9 & - & 9.6 & 30.8 & - & 40.2 & 7.9 & 33.8 & 0.7 & 1.7 \\
\hline \multicolumn{12}{|l|}{ Claw 1 heights } \\
\hline External base & 30 & 2.4 & - & 5.3 & 12.6 & - & 21.8 & 4.2 & 17.7 & 0.7 & 2.2 \\
\hline External primary branch & 30 & 5.5 & - & 9.6 & 25.8 & - & 40.4 & 7.7 & 33.0 & 0.9 & 3.4 \\
\hline External secondary branch & 30 & 2.8 & - & 4.9 & 14.6 & - & 20.4 & 4.2 & 18.0 & 0.5 & 1.5 \\
\hline External total & 30 & 8.3 & - & 15.2 & 40.9 & - & 63.8 & 12.1 & 51.5 & 1.5 & 4.9 \\
\hline Internal base & 28 & 2.9 & - & 4.4 & 13.3 & - & 17.6 & 3.7 & 15.6 & 0.4 & 1.1 \\
\hline Internal primary branch & 27 & 4.0 & - & 5.7 & 18.0 & - & 24.0 & 4.9 & 21.0 & 0.4 & 1.6 \\
\hline Internal secondary branch & 27 & 2.7 & - & 5.1 & 11.8 & - & 20.0 & 3.7 & 15.5 & 0.6 & 2.0 \\
\hline Internal total & 27 & 6.7 & - & 9.5 & 29.6 & - & 39.6 & 7.9 & 33.7 & 0.6 & 2.2 \\
\hline \multicolumn{12}{|l|}{ Claw 2 heights } \\
\hline External base & 30 & 2.7 & - & 6.0 & 14.4 & - & 25.1 & 4.6 & 19.5 & 0.8 & 2.6 \\
\hline External primary branch & 30 & 5.7 & - & 11.3 & 29.3 & - & 47.2 & 8.6 & 36.7 & 1.0 & 3.4 \\
\hline External secondary branch & 30 & 2.8 & - & 5.8 & 14.6 & - & 23.8 & 4.5 & 19.3 & 0.7 & 2.0 \\
\hline External total & 29 & 8.7 & - & 17.0 & 43.6 & - & 71.3 & 13.4 & 57.1 & 1.7 & 5.2 \\
\hline Internal base & 27 & 2.8 & - & 4.7 & 12.7 & - & 18.8 & 3.9 & 16.4 & 0.5 & 1.4 \\
\hline Internal primary branch & 26 & 3.7 & - & 6.7 & 17.5 & - & 25.8 & 5.2 & 22.2 & 0.6 & 1.9 \\
\hline Internal secondary branch & 26 & 2.1 & - & 5.4 & 11.1 & - & 21.4 & 4.0 & 16.7 & 0.7 & 2.1 \\
\hline Internal total & 26 & 6.2 & - & 10.2 & 29.8 & - & 42.5 & 8.4 & 35.8 & 0.9 & 2.6 \\
\hline \multicolumn{12}{|l|}{ Claw 3 heights } \\
\hline External base & 26 & 2.7 & - & 6.3 & 14.2 & - & 25.3 & 4.6 & 19.8 & 0.8 & 2.6 \\
\hline External primary branch & 26 & 6.1 & - & 11.7 & 28.1 & - & 48.8 & 8.4 & 35.8 & 1.2 & 4.4 \\
\hline External secondary branch & 26 & 2.8 & - & 5.9 & 14.9 & - & 24.2 & 4.7 & 19.9 & 0.7 & 2.0 \\
\hline External total & 25 & 9.0 & - & 18.1 & 42.2 & - & 75.7 & 13.1 & 56.2 & 2.0 & 6.6 \\
\hline Internal base & 21 & 2.6 & - & 4.9 & 13.9 & - & 19.2 & 3.9 & 16.8 & 0.5 & 1.2 \\
\hline Internal primary branch & 19 & 4.0 & - & 6.6 & 18.3 & - & 27.6 & 5.1 & 22.1 & 0.6 & 2.0 \\
\hline Internal secondary branch & 21 & 2.6 & - & 5.4 & 13.7 & - & 21.3 & 4.0 & 16.9 & 0.7 & 2.2 \\
\hline Internal total & 20 & 6.4 & - & 10.4 & 31.7 & - & 43.3 & 8.4 & 36.2 & 0.9 & 2.8 \\
\hline \multicolumn{12}{|l|}{ Claw 4 lengths } \\
\hline Anterior base & 24 & 2.7 & - & 4.8 & 13.0 & - & 19.3 & 4.0 & 16.7 & 0.5 & 1.4 \\
\hline
\end{tabular}


Table 3 (continued).

\begin{tabular}{lcccccccccccc}
\hline & \multirow{2}{*}{} & \multicolumn{4}{c}{ RANGE } & \multicolumn{3}{c}{ MEAN } & \multicolumn{3}{c}{ SD } \\
\cline { 3 - 12 } & & \multicolumn{2}{c}{$\boldsymbol{\mu} \mathbf{m}$} & & $\boldsymbol{p} \boldsymbol{t}$ & & $\boldsymbol{\mu m}$ & $\boldsymbol{p t}$ & $\boldsymbol{\mu m}$ & $\boldsymbol{p t}$ \\
\hline Anterior primary branch & 24 & 4.6 & - & 6.4 & 19.9 & - & 27.0 & 5.4 & 23.1 & 0.4 & 1.6 \\
Anterior secondary branch & 24 & 2.8 & - & 5.2 & 14.7 & - & 20.9 & 4.4 & 18.7 & 0.6 & 1.6 \\
Anterior total & 24 & 7.1 & - & 11.0 & 31.3 & - & 46.1 & 9.0 & 38.2 & 0.9 & 2.8 \\
Posterior base & 28 & 3.1 & - & 6.1 & 15.0 & - & 24.4 & 5.2 & 21.8 & 0.7 & 2.3 \\
Posterior primary branch & 28 & 8.0 & - & 14.5 & 37.7 & - & 60.6 & 11.5 & 48.7 & 1.3 & 4.0 \\
Posterior secondary branch & 28 & 3.8 & - & 6.4 & 15.8 & - & 25.7 & 5.4 & 23.0 & 0.7 & 2.5 \\
Posterior total & 28 & 11.4 & - & 20.0 & 52.9 & - & 83.8 & 16.8 & 71.3 & 2.0 & 5.7 \\
\hline
\end{tabular}

ITS-2 sequence (GenBank: MN927181), 486 bp long:

All obtained sequences were deposited in GenBank (https://www.ncbi.nlm.nih.gov/genbank/) under the following accession numbers: MK967241, MN915220, MN915221, MN918533, MN919385 (COI), MK973069, MN912103 (18S rRNA); MK967961, MK967962, MK967963, MK967964 (28S rRNA); MN927181, MN927182 (ITS-2).

\section{Phylogenetic analysis}

In the 18S DNA phylogenetic analysis, the order Hypsibioidea was highly supported and divided into two well-supported clades: clade I, embracing the family Ramazzottiidae, Marley, McInnes \& Sands, 2011, and clade II, comprised of taxa currently attributed to the families Hypsibiidae Pilato, 1969, Calohypsibiidae Pilato, 1969 and Microhypsibiidae Pilato, 1998 (Fig. 8). Clade II was further divided into two subclades well-supported with Bayesian analysis, but weakly supported or unsupported with ML analysis. The first subclade included the families Microhypsibiidae s. str. (genus Microhypsibius Thulin, 1928) and Calohypsibiidae s.str. (genus Calohypsibius Thulin, 1928) (see Gąsiorek et al. 2019a for a discussion on the taxonomic composition of these two families), together with two genera of unclear taxonomic position, Acutuncus and Mixibius. The second subclade was divided into three subclades with unclearly resolved phylogenetic relationships. The first of these subclades included the species representing the subfamily Pilatobiinae Bertolani, Guidetti, Marchioro, Altiero, Rebecchi \& Cesari, 2014, Hypsbius pallidoides, and the species attributed to Hypsibius convergens (Urbanowicz, 1925) by Guil \& Giribet (2012). The second one included the species of the subfamily Itaquasconinae Rudescu, 1964 and the third one was comprised of two well-supported lineages, the subfamilies Diphasconinae Dastych, 1992 and Hypsibiinae Pilato, 1969.

Analyses of the concatenated $18 \mathrm{~S}+28 \mathrm{~S}$ sequences resulted in a phylogeny with the same tree configuration, but with slightly weaker support of the clades (see Supplementary file SM.02). This weakened support is possibly a consequence of the small number of sequences available for such analysis.

\section{Comparison with the original description}

Morphometry of specimens from all analysed populations (including the type series) corresponds well with the data from the original description (Pilato et al. 2011). Small differences in the values of the stylet supports insertion point $p t$ index (54.2-55.2 in the original description vs 56.9-63.3 in the material investigated) and the length of the first macroplacoid (3.8-4.2 $\mu \mathrm{m}$ ( $p t$ 15.5-17.0) vs $2.2-3.8 \mu \mathrm{m}$ (11.215.9) respectively) should be considered as the result of some differences in the measuring process, taking into account that my own measurements of the type series specimens are concordant with those of the specimens from the other populations (see Table 2). 

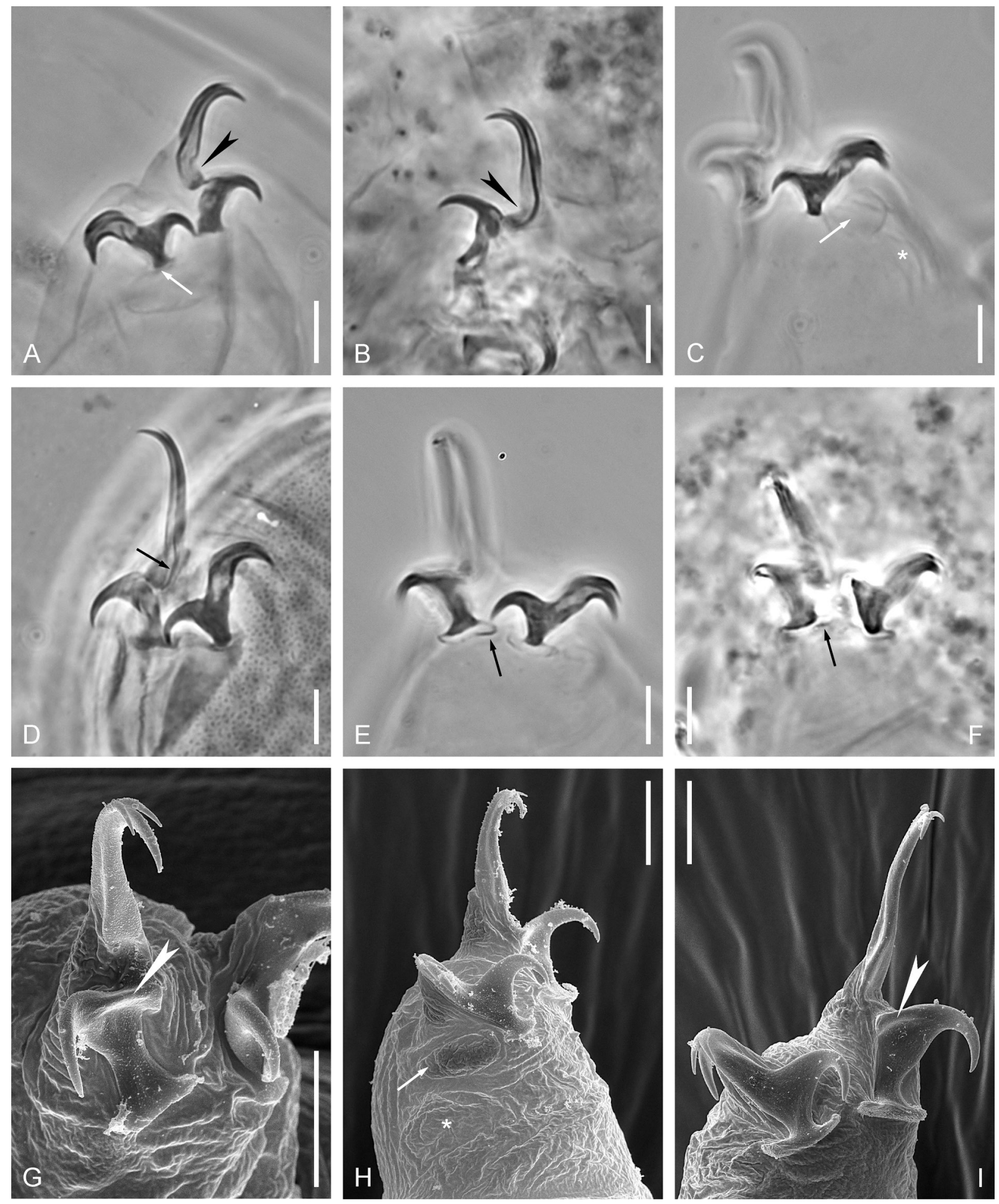
It was stated in the original description (Pilato et al. 2011) that $H$. pallidoides had a smooth cuticle, but high quality LM and SEM observations revealed the presence of a cuticular sculpture (Figs 2A-D, 3AB). It is poorly visible in the type series specimens because of the intensive staining of soft tissues with acetocarmine during the slide preparation.

Contrary to the absence of lunules in H. pallidoides stated by Pilato et al. (2011), my investigation determined that scarcely visible lunules on the claws of legs I-III and well-developed wide lunules on the claws of legs IV are present (Fig. 6A, E). In the original description of the species, Pilato et al. (2011) indicated the absence of a cuticular bar between the claw bases of legs IV, but considered this as unconfirmed. My observations revealed the presence of a thickened zone of the posterior claw lunule, located between the anterior and the posterior claw bases (Fig. 6E-F). This thickening can give the impression of a cuticular bar in the case when the main part of the lunule is not discernible.

While Pilato et al. (2011) described the eggs of $H$. pallidoides as being smooth, further scrutiny ascertained the presence of a granular pattern formed by the system of internal pillars in the egg shell of this species (Fig. 7B-G).

\section{New phenotypic differential diagnosis}

Hypsibius pallidoides is similar to the species of the genera Ramazzottius Binda \& Pilato, 1986 and Cryoconicus Zawierucha, Stec, Lochowska-Cierlik, Takeuchi, Li \& Michalczyk, 2018 in having claws of the Ramazzottius type; AISM asymmetrical with respect to the frontal plane; cephalic elliptical sensory organs and in laying ornamented eggs. It clearly differs from all species of those genera by having wider primary branches of the external and posterior claws, with less pronounced differentiation between rigid distal and soft basal parts; the dorsal AISM raised and thickened in its anterior margin, and eggs laid in the exuvium without external processes, but with pillars inside the egg shell only.

Hypsibius pallidoides is similar to the species of the genus Mixibius in having AISM asymmetrical with respect to the frontal plane, where the ventral apophysis is similar, but not identical, to the "semilunar hook" of Hypsibius; dorsal apophysis more stumpy with a blunt and swollen caudal apex. Also a short median cuticular thickening caudal to both these apophyses is present (the ventral one slightly visible) (Pilato \& Binda 2010). It clearly differs from all species of this genus by having: cephalic elliptical sensory organs and Ramazzottius-like claws (external claws with elongated primary branches and less developed secondary branches).

The type of egg shell sculpture of Hypsibius pallidoides is similar to that of Acutuncus antarcticus, from the Antarctic region (see Dastych 1991 for a review of the old records) in that the sculpture,

Fig. 6 (opposite page). Hypsibius pallidoides Pilato, Kiosya, Lisi, Inshina \& Biserov, 2011, claws. Specimens SPbU 251(82) (A, C, E) and KNU Чep-9 II (B, D, F). A. Claws of leg I, black arrowhead indicates the flexible part of the external claw main branch, black arrows indicates the lunule of the internal claw, PhC. B. Claws of leg III, type series specimen, black arrowhead indicates the flexible part of the external claw main branch, PhC. C. Claws of leg II, white arrow indicates the elongated bulge near the base of the internal claw, white asterisk - pulvilla on the inner side of the leg, PhC. D. Claws of leg IV, type series specimen, black arrow indicates the filamentous structure connecting the external claw main branch with the claw base, PhC. E. Claws of leg IV, black arrow indicates the thickened region on the lunule margin, PhC. F. Claws of leg IV, type series specimen, black arrow indicates the thickened region on the lunule margin, PhC. G. Claws of leg II, white arrowhead indicates the lateral crest of the claw base, SEM. H. Claws of leg III, white arrow indicates the elongated bulge near the base of the internal claw, white asterisk - pulvilla on the inner side of the leg, SEM. I. Claws of leg IV, white arrowhead indicates the lateral crest of the claw base, SEM. 

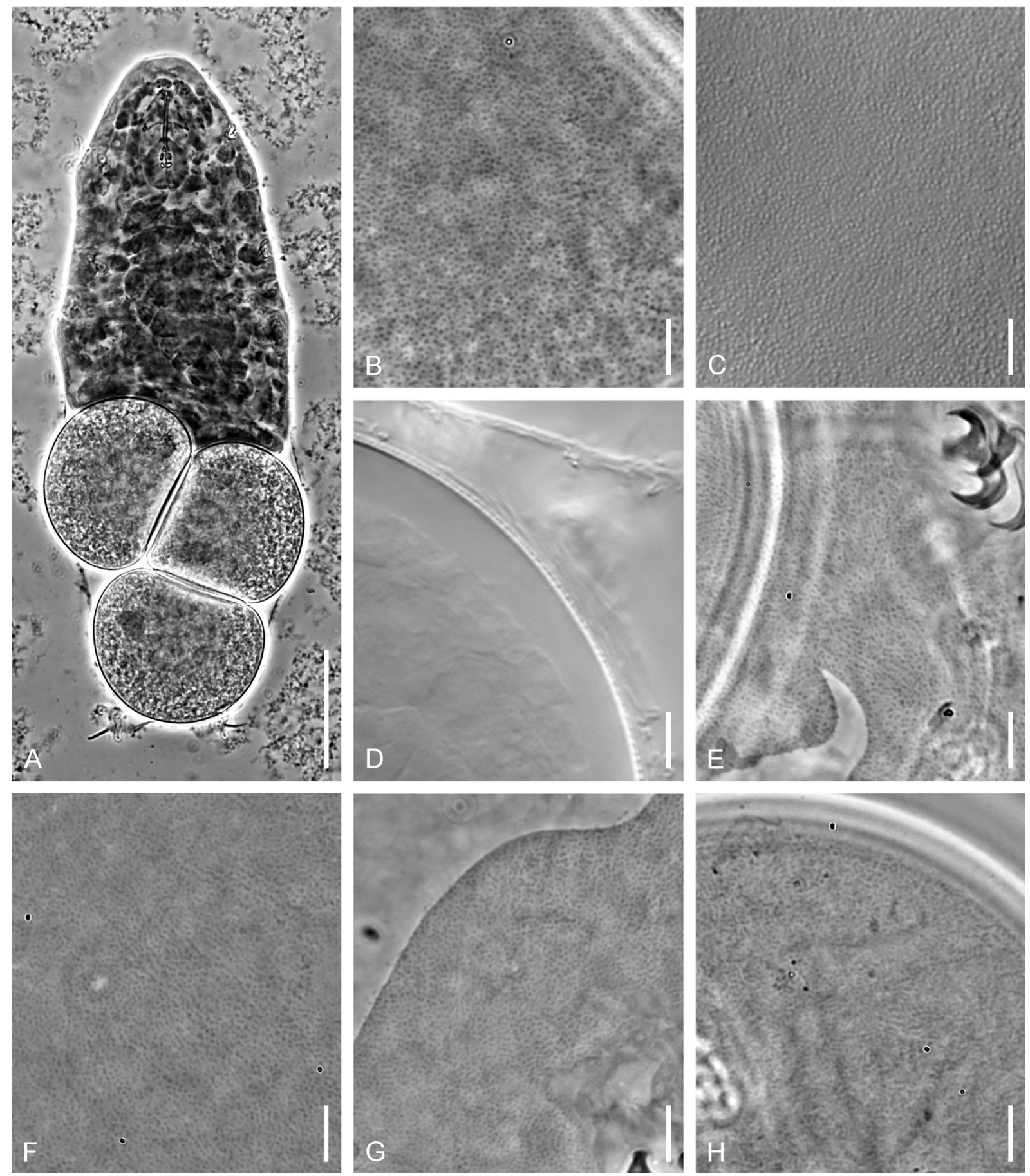

Fig. 7. A-G. Hypsibius pallidoides Pilato, Kiosya, Lisi, Inshina \& Biserov, 2011 eggs. A-D, specimen KNU Чep-9 II. A. Type series specimen mounted during the egg laying process, PhC. B. Type series egg shell, PhC. C. Type series egg shell, DIC. D. Type series egg shell structure with numerous internal pillars visible, DIC. E. Austrian population egg shell (SPbU 251(3)), PhC. F. Karelian population egg shell (SPbU 113(2)), PhC. G. Pushkin population egg shell (SPbU 235(28)), PhC. - H. Pilatobius recamieri (Richters, 1911), egg shell (SPbU 203(7)), PhC. Scale bars: A $=50 \mu \mathrm{m}$; B-H $=5 \mu \mathrm{m}$. 
formed by the pillars within the egg shell, presents as a dot-like pattern when observed in LM. Hypsibius pallidoides differs from $A$. antarcticus by having the Ramazzottius-type claws; AISM asymmetrical with respect to the frontal plane; a sculptured cuticle and a small dot-like septulum. The precise nature of the latter structure requires further investigation as its small size prevents it from being undoubtedly interpreted as microplacoid or septulum.

Hypsibius pallidoides is similar to the following species of the genus Hypsibius: Hypsibius allisoni Horning, Schuster \& Grigarick, 1978 (known from New Zealand and South America (Horning et al. 1978; Maucci 1988; Pilato et al. 2003)); H. murrayi (=H. heardensis Miller, McInnes \& Bergstrom, 2005; known from Antarctica (Dastych 2018)) and H. pachyunguis Maucci, 1996 (known from Greenland).

Hypsibius pallidoides clearly differs from the above mentioned species by having the Ramazzottius-like claws and by having cuticular sculpture. Additionally, $H$. pallidoides differs from:

Hypsibius allisoni by having a thinner buccal tube (external width up to $2.1 \mu \mathrm{m}$ in $H$. pallidoides vs $4 \mu \mathrm{m}$ in H. allisoni holotype) (Horning et al. 1978).

Hypsibius murrayi by the absence of cuticular bars near the claw bases of legs I-III, by having a dot-like pattern of the egg shell, a smaller body length (up to $292 \mu \mathrm{m}$ in H. pallidoides vs 338.0-603.0 $\mu \mathrm{m}$ in H. murrayi) (Dastych 2018).

Hypsibius pachyunguis by having less elongated macroplacoids (see Maucci 1996: 196, fig. 1; Tumanov 2018: 440, fig. 4a-b).

Two species of the genus Hypsibius are known as laying eggs with granulated chorion in exuvium, Hypsibius roanensis Nelson \& McGlothlin, 1993 (Guidetti et al. 1999) and H. cf. scabropygus (Guidetti \& Bertolani 2001). Hypsibius pallidoides clearly differs from both of these species by having a septulum, the Ramazzottius-like claws, and a different cuticular sculpture.

\section{Genotypic differential diagnosis}

The ranges of uncorrected genetic $p$-distances between the studied population of Hypsibius pallidoides and species of the order Hypsibioidea for which sequences are available from GenBank (see Supplementary file SM.01) are as follows:

COI: $20.9 \%-26.7 \%$ (mean 23.0\%), with the most similar being Pilatobius recamieri (Richters, 1911) (KX347530, Gąsiorek et al. 2017), and the least similar being Diphascon puniceum (Jennings, 1976) (KP013612, Velasco-Castrillón et al. 2015).

18S rRNA: $2.0 \%-8.7 \%$ (mean 6.2\%), with the most similar being Pilatobius recamieri (KX347526, Gąsiorek et al. 2017) and P. islandicus Buda, Olszanowski, Wierzgoń \& Zawierucha, 2018 (MH682258, Buda et al. 2018), and the least similar being Diphascon puniceum (EU266948, Sands et al. 2008).

28S rRNA: 5.9\%-18.7\% (mean 11.2\%), with the most similar being Mesocrista revelata Gąsiorek, Stec, Morek, Zawierucha, Kaczmarek, Lachowska-Cierlik \& Michalczyk, 2016 (KX347536, Gąsiorek et al. 2016), and the least similar being Ramazzottius varieornatus Bertolani \& Kinchin, 1993 (MG432818, Zawierucha et al. 2018).

ITS-2: $19.6 \%-45.1 \%$ (mean 38.2\%), with the most similar being Pilatobius recamieri (KX347528, Gąsiorek et al. 2017), and the least similar being Ramazzottius subanomalus (Biserov, 1985) (KU900019, Stec et al. 2016b). 


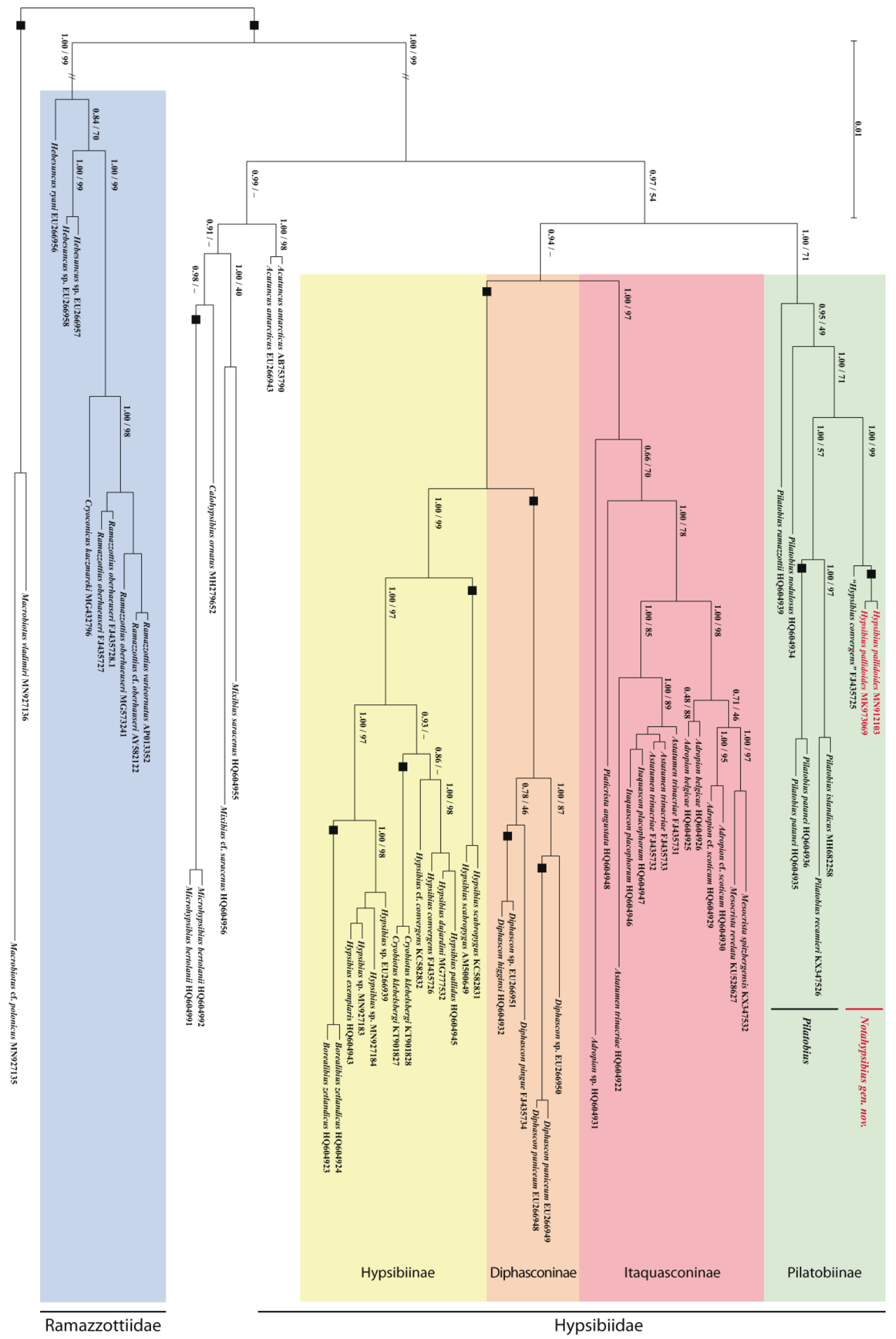


Full matrices with $p$-distances are provided in the Supplementary file SM.03.

Sequences of the $18 \mathrm{~S}$ and $28 \mathrm{~S}$ rRNA genes, attributed to the species "Hypsibius convergens" by Guil \& Giribet (2012) are nearly identical to those of Hypsibius pallidoides ( $p$-distances $0.0 \%$ and $1.1 \%$ respectively).

\section{Phylogeny of Hypsibioidea and phylogenetic position of Hypsibius pallidoides}

The results of phylogenetic analysis presented herein correspond well with the molecular phylogenies of Tardigrada reconstructed in the recent works of other researchers (Guil \& Giribet 2012; Bertolani et al. 2014; Guil et al. 2019), being most similar to the results of Bertolani et al. (2014). In comparison with the results of Guil et al. (2019), some differences in the tree topology may be attributable to a different approach taken in the selection of the compared sequences. In my opinion, the position of some sequences attributed to the species Acutuncus antarcticus within the cluster of species of Hypsibius (Guil et al. 2019: fig. 2) and the unclear differentiation of the Itaquasconinae and Hypsibiinae lineages are artefacts, caused by the inclusion of sequences derived from pooled samples which could contain multiple species (Sands et al. 2008), or by misidentifications of the sequenced specimens (see below).

My phylogenetic analysis confirmed the presence of the weakly supported but distinct basal clade within Hypsibiidae that includes the genera Acutuncus, Mixibius, Calohypsibius and Microhypsibius. With the addition of recently published data for two species of the genus Pilatobius Bertolani, Guidetti, Marchioro, Altiero, Rebecchi \& Cesari, 2014 (Gąsiorek et al. 2017; Buda et al. 2018), the Pilatobiinae clade, recognized in the analysis of Bertolani et al. (2014), became better supported in my analysis. Surprisingly, Hypsibius pallidoides (and a species attributed to H. convergens by Guil \& Giribet (2012)) were distinctly placed within the Pilatobiinae clade, and even more interestingly within the genus Pilatobiotus itself, forming a cluster with the species $P$. patanei (Binda \& Pilato, 1971)/ P. islandicus/ P recamieri, while the species P. ramazzottii (Robotti, 1970) and P. nodulosus (Ramazzotti, 1957) formed a separate paraphyletic group. Grouping of the species attributed to H. convergens with Pilatobius recamieri was obtained by Guil et al. (2019), but this result was not discussed by the authors. In an earlier publication (Guil \& Giribet 2012), the taxon misidentified with $H$. convergens was joined with Astatumen trinacriae (Arcidiacono, 1962), but this result is likely an artefact because no species of Pilatobius were used in the analysis. In my opinion, extreme similarity of the $18 \mathrm{~S}$ and $28 \mathrm{~S}$ sequences of this species to the sequences of $H$. pallidoides ( $p$-distances $0.0 \%$ and $1.1 \%$ respectively) should be considered as evidence of their identity on the genus level. Hypsibius pallidoides is morphologically similar to H. convergens and could be misidentified with this species, especially when temporary slides were used for the identification (Guil\& Giribet 2012), because of the poor visibility of the cuticular sculpture and septulum in living specimens.

As a result, in the case of $H$. pallidoides we have a distinct contradiction between the morphological and molecular taxonomical approaches. Analysis of the morphological traits of this species reveals similarities with Ramazzottiidae (i.e., presence of the cephalic elliptical organs, the Ramazzottius-like claws, asymmetry of the AISM), but, according to the analysis of the gene sequences, this species should be attributed to the subfamily Pilatobiinae. Its position in the obtained phylogenetic tree also supports the presumably paraphyletic nature of the genus Pilatobius, also inferred by Gąsiorek et al. (2018). To my knowledge, this is the first occurrence of such a distinct controversy between morphological and molecular taxonomy within Tardigrada. Previously, genetic analyses have supported

Fig. 8 (opposite page). The phylogeny of Hypsibioidea based on 18S rRNA seqences. Numbers at nodes indicate Bayesian posterior probability values (BI, first values) and bootstrap values (ML, second values). Black dots indicate the nodes supported by values of $1.0 / 100 \%$ with both methods. Scale bar and branch lengths refer to the Bayesian analysis. 
the erection of taxa recognized by traditional morphological analysis (e.g., genera Paramacrobiotus Guidetti, Schill, Bertolani, Dandekar \& Wolf, 2009, Mesobiotus Vecchi, Cesari, Bertolani, Jönsson, Rebecchi \& Guidetti, 2016, Acantechiniscus Vecchi, Cesari, Bertolani, Jönsson, Rebecchi \& Guidetti, 2016, family Ramazzottiidae, order Isohypsibioidea) (Guidetti et al. 2009; Vecchi et al. 2016; Sands et al. 2008) or provided an opportunity to resolve the phylogeny of a group when morphological data were insufficient (e.g., the clarification of the phylogenetic position of the genera Apodibius Dastych, 1983 and Haplomacrobiotus May, 1948, revisions of Isohypsibioidea and Echiniscus C.A.S. Schultze, 1840) (Dabert et al. 2014; Cesari et al. 2016; Gąsiorek et al. 2019b, 2019c). The presence of such controversy is a problem that has been acknowledged in current zoology since molecular methods began to be widely used (Hillis 1987; Osawa et al. 2004; Smirnov et al. 2005; Cohen 2018). Various authors who have analysed this problem (Hedges \& Sibley 1994; Scotland et al. 2003; Osawa et al. 2004; Wiens 2004; Smith \& Turner 2005) came to the conclusion that the best (if not the only) way to align the conflicting morphological and molecular phylogenies is to improve the morphological data by involving new characters in the analysis and by re-evaluating some characters already in use.

Taking into account the unique combination of the morphological features and the phylogenetic position of Hypsibius pallidoides distant from the remaining species of Hypsibius, as demonstrated by the analysis of the molecular data, the erection of the new genus Notahypsibius gen. nov. for the species H. pallidoides is proposed.

\title{
Taxonomic account
}

\author{
Genus Notahypsibius gen. nov. \\ urn:lsid:zoobank.org:act:EDAD9932-04DD-4926-BEAA-369E0AA074C5
}

\section{Type species}

Hypsibius pallidoides Pilato, Kiosya, Lisi, Inshina \& Biserov, 2011

\section{Diagnosis}

Hypsibiidae with Ramazzottius-like claws and completely rigid buccal tube. Apophyses for the insertion of the stylet muscles asymmetrical, dorsal AISM shorter and higher than ventral, with thickened anterior margin. Pharynx with two elongated macroplacoids and minute dot-like septulum. Cephalic elliptical organs present. Rugose cuticular sculpture. Eggs laid within the exuvium (or freely?), chorion with developed pillar-like internal structure visible in LM.

\section{Etymology}

The name refers to the phylogenetic position of the new genus, the type species of which was originally described as belonging to genus Hypsibius, but according to the phylogenetic analysis, definitely is "not a Hypsibius".

Genus composition (three species)

Notahypsibius pallidoides (Pilato, Kiosya, Lisi, Inshina \& Biserov, 2011) gen. et comb. nov. Figs 1-7, Tab. 2, 3

Hypsibius pallidoides Pilato, Kiosya, Lisi, Inshina \& Biserov, 2011: 13-15, fig. 7a-d (description). 


\section{Geographical distribution}

This species was described from Kherson Oblast, South Ukraine (Pilato et al. 2011). Later it was recorded for the Minsk Oblast, Central Belarus (Pilato et al. 2012) and Sicily (Lisi 2015). My observations extend the distribution of this species to North-West Russia (St Petersburg and Karelia), Croatia and Austria (Carinthia). It should be noted that Dastych (1988) observed a configuration of the bucco-pharyngeal apparatus similar to $N$. pallidoides gen. et comb. nov. in some Polish specimens attributed by him to H. convergens (Dastych 1988: 147, pl. XXIa, c). Also, some of the microphotographs of the claws of Dastych's specimens of $H$. convergens show a similarity to those described for $N$. pallidoides gen. et comb. nov. (Dastych 1988: pl. XXIi). So, it is very likely that the latter species is present among the tardigrade fauna of Poland. The species attributed to as "H. convergens" by Guil \& Giribet (2012) is nearly identical to $N$. pallidoides gen. et comb. nov. in $18 \mathrm{~S}$ and $28 \mathrm{~S}$ gene sequences (see Genotypic differential diagnosis). In my opinion, this is evidence for the presence of $N$. pallidoides gen. et comb. nov. in Spain, but it was recently shown (Guidetti et al. 2019a) that closely related species can share an identical 18S rRNA haplotype. Thus, without analyses of the more sensitive barcode genes (particularly COI and ITS-2), and in the absence of morphological data, the possibility of the presence of another species similar to $N$. pallidoides gen. et comb. nov. in Spain cannot be excluded.

Notahypsibius scaber (Maucci, 1987) gen. et comb. nov.

Fig. 9A-I

Hypsibius scaber Maucci, 1987: 200, figs 11-12 (description).

\section{Material examined}

\section{Holotype}

USA • Yellowstone Park, near Undina Falls; Aug. 1984; W. Maucci leg.; moss on tree trunk; MCVR C.T. 12289.

\section{Paratype}

USA • 1 spec.; same collection data as for holotype; MCVR C.T. 12288.

\section{Notes}

The species described as Hypsibius scaber Maucci, 1987 (known from North America only; Maucci 1987 ) is very similar to $N$. pallidoides gen. et comb. nov. in having cuticular sculpture consisting of irregular ridges (Fig. 9A-B, D-E), highly differentiated external and internal claws that closely resemble the Ramazzottius-type claws (Fig. 9H-I), and a similar bucco-pharyngeal apparatus with a thin buccal tube and minute dot-like septulum (Fig. 9C, F). In my opinion, it should be transferred to the genus Notahypsibius gen. nov. as Notahypsibius scaber gen. et comb. nov. It seems also that $N$. scaber gen. et comb. nov. has cephalic elliptical organs (Fig. 9G), but their presence requires further confirmation because of the difficulties in observing the dorsal surface of the type specimens (R. Guidetti, pers. com.). Notahypsibius pallidoides gen. et comb. nov. differs from N. scaber gen. et comb. nov. in having a less developed cuticular sculpture, especially on the ventral side of the body (Fig. 9D-E), and in having external claws with the common base thinner and longer in relation to the secondary branch. It should be noted that the comparison of $N$. pallidoides gen. et comb. nov. with $N$. scaber gen. et comb. nov. cannot be considered to have definitively resolved the possible synonymy of these species. The latter species description was based on only two specimens, both of which have most of their claws in positions that obstruct observation and correct measurement. Also, the eggs of $N$. scaber gen. et comb. nov. are unknown. 

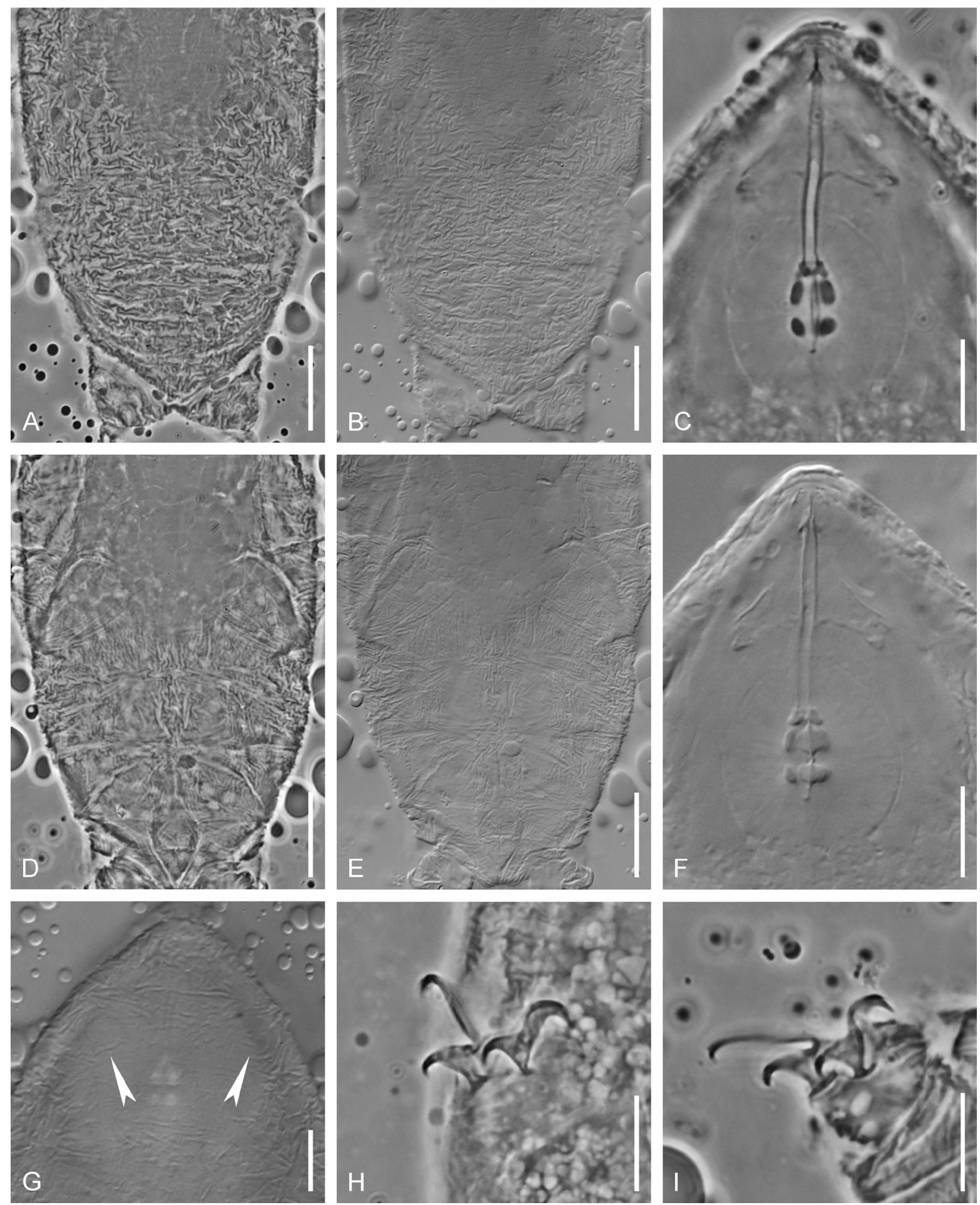

Fig. 9. Hypsibius scaber Maucci, 1987, holotype (MCVR C.T. 12289) (A-G, I) and paratype (MCVR C.T. 12288) (H). A. Dorsal view of the caudal body end, PhC. B. Dorsal view of the caudal body end, DIC. C. Bucco-pharyngeal apparatus, PhC. D. Ventral view of the caudal body end, PhC. E. Ventral view of the caudal body end, DIC. F. Bucco-pharyngeal apparatus, DIC. G. Dorsal surface of the head region, white arrowheads indicate the presumable elliptical sensory organs, DIC. H. Claws of leg III, PhC. I. Claws of leg IV, PhC. Scale bars: A-B, D-E $=20 \mu \mathrm{m} ; \mathrm{C}, \mathrm{F}-\mathrm{I}=10 \mu \mathrm{m}$. Photo G presented by R. Guidetti, University of Modena and Reggio Emilia, Italy. 
Notahypsibius arcticus (Murray, 1907) gen. et comb. nov.

Macrobiotus arcticus Murray, 1907b: 677, pl. 1, fig. 5a-f(description).

Macrobiotus heinisi Richters, 1911: 15, fig. 15.

Hypsibius arcticus - Thulin 1911: 27. — Marcus 1930: 380. — Dastych 1991: 141-159 (taxonomical notes).

Ramazzottius arcticus Gąsiorek et al. 2018: 52.

\section{Type locality}

Franz Joseph Land (Murray 1907b).

\section{Notes}

The species Hypsibius arcticus (Murray, 1907) was recently transferred by Gąsiorek et al. (2018) to the genus Ramazzottius on the basis of having Ramazzottius-like claws and freely laid eggs. In my opinion, the type of the chorion ornamentation in this species, consisting of the internal pillars, is definitely different from the external processes that are typical of the genus Ramazzottius (see Discussion). The combination of the Ramazzottius-like claws and eggs with developed internal pillars in the egg chorion makes this species more similar to $N$. pallidoides gen. et comb. nov. It should, therefore, be transferred to the new genus as Notahypsibius arcticus gen. et comb. nov. This species differs from N. pallidoides gen. et comb. nov. by having better developed pillars in the egg chorion and by laying free eggs. However, the latter trait requires confirmation as it is assumed upon the basis of a single observation (Murray 1907b), especially taking into consideration that Macrobiotus heinisi (Richters, 1911) - a similar species described from the same locality (Franz Joseph Land) and later synonymized with $\mathrm{H}$. arcticus (Marcus 1930) - has eggs with a similar chorion structure laid within the exuvium (Richters 1911). Also, Acutuncus antarcticus, which shares an eggshell structure of a similar appearance, is known to lay eggs both within the exuvium and freely (Dastych 1991; pers. obs.). Other key characteristics, such as the presence of the minute septulum and cuticular sculpture, may have been overlooked by Murray (1907b) in his original description, as visualisation of these structures requires the use of high quality optics unavailable at that time. The specimen and the egg from Scotland, which were described and figured by Murray (1907a: 658, pl. IV, fig. 27a-d) as "Macrobiotus oberhäuseri Doy. ?", could not be attributed to $N$. arcticus gen. et comb. nov. because of the evident differencies in the claw structure (claws similar to the Cryoconicus type), the egg chorion appearance (much shorter pillars), and the significant difference in the value of the $p t$ index for the stylet support insertion point $(57 \%$ in Scottish specimen vs $70 \%$ in $N$. arcticus gen. et comb. nov., measurements taken from the original Murray's drawings). This material possibly represents an undescribed species of the genus Cryoconicus.

\section{Discussion}

\section{Phylogenetic significance of some morphological characters}

\section{Ramazzottius-like claws}

Morphology of the claws is one of the most important characters used in the taxonomy of Eutardigrada (Pilato 1969; Schuster et al. 1980; Pilato \& Binda 2010; Gąsiorek et al. 2019c). Ramazzottius type claws were recognized as a separate morphotype (and denominated as "oberhaeuseri type" claws) by Binda \& Pilato (1986) with the simultaneous erection of the genus Ramazzottius and were recently reanalysed by Guidetti et al. (2019b). Two other genera, Ramajendas Pilato \& Binda, 1990 and Thalerius Dastych, 2009, were recognized as having a similar claw morphology (Pilato \& Binda 1990; Dastych 2009). The phylogenetic and taxonomic position of these two genera is currently the subject of debate because of the evident controversy in their morphology and lack of DNA sequences. Being initially placed 
within Isohypsibiidae (Marley et al. 2011; Guil et al. 2013), both genera were later attributed to the family Ramazzottiidae by Bertolani et al. (2014) on the basis of claw morphology. Zawierucha et al. (2018), taking into account the simple ridge-like form of the apophyses for the insertion of the stylet muscles and the deposition of smooth eggs in the exuvium known in the genus Ramajendas, proposed to place both of these genera back within Isohypsibiidae, suggesting the independent evolution of the Ramazzottius-like claws. Thus, for clarity, I use here the term "Ramazzottius-like claws" in order to distinguish the claws of Ramajendas, Thalerius and Notahypsibius gen. nov. from the Ramazzottiustype claws of Ramazzottiidae (see Guidetti et al. 2019b for a discussion). In a recent revision of the order Isohypsibioidea, Ramajendas and Thalerius are considered as incertae sedis pending molecular verification of their taxonomic positions (Gąsiorek et al. 2019c). In this situation, the obtained data showing the independent evolution of the Ramazzottius-like claws within the Pilatobiinae clade should be considered as an argument in favour of the hypothesis that Ramajendas and Thalerius are positioned phylogenetically distant from Ramazzottiidae.

\section{Cephalic elliptical organs}

Binda \& Pilato (1986) pointed out the presence of these structures in the genus Ramazzottius and compared them with the papillae in the cephalic region of Calohypsibius ornatus (Richters, 1900). Since the genus Fractonotus Pilato, 1998, in which these structures are also known, was revised and transferred to the family Isohypsibiidae (Gąsiorek et al. 2019a, 2019c) the cephalic elliptical organs are currently known within two Eutardigrada orders, Hypsibioidea (Calohypsibius and Notahypsibius gen. nov.) and Isohypsibioidea (Fractonotus). These structures should not be confused with 'cephalic papillae' or 'frontal lobes' known in several Isohypsibiidae genera (Halobiotus Kristensen, 1982, Apodibius, Ursulinius Gąsiorek, Stec, Morek \& Michalczyk, 2019 and Paradiphascon Dastych, 1992) (Gąsiorek et al. 2019c) regarding the much more rostral position of the latter structures (within the anteriormost cephalic pseudosegment). Cephalic elliptical organs are located more caudally on the second pseudosegment following the cephalic one. In my opinion, only fronto-lateral porous areas of N. pallidoides (Fig. 4A-B) can be matched with the 'cephalic papillae' or 'frontal lobes' of Isohypsibiidae. Taking into account that cuticular sensory structures of Eutardigrada are very likely homologous to the cephalic sensory structures of Heterotardigrada (Zantke et al. 2008), the presence of such organs should be considered a plesiomorphic state and so supports the hypothesis of the basal phylogenetic position of Hypsibioidea and Isohypsibioidea (Marley et al. 2011; Gąsiorek et al. 2019c).

\section{Chorion structure}

Although egg shell structure has been considered a valuable taxonomic character within Eutardigrada from the early years of its investigation (Marcus 1929, 1936; Ramazzotti \& Maucci 1983), the phylogenetic significance of this trait was revealed considerably later (Bertolani et al. 1996). In their analysis, Bertolani and colleagues identified two types of the organization of the egg chorion - "smooth" and "ornamented" - and attributed A. antarcticus eggs to the ornamented type. In my opinion, the boundary between these two egg shell morphotypes within Tardigrada is not so obvious and the delimitation should be different.

Following the transfer of $R$. arcticus to the genus Notahypsibius gen. nov., there are only three genera known within Hypsibioidea with an egg chorion internal structure consisting of numerous pillars that connect the outer and inner layers of the shell: Acutuncus (Dastych 1991), Notahypsibius gen. nov. (present paper), and Pilatobius (present paper, see below). Additionally, two species of the genus Hypsibius (H. roanensis Nelson \& McGlothlin, 1993 and H. cf. scabropygus) have finely granulated egg shells (Guidetti et al. 1999; Guidetti \& Bertolani 2001). The similarity to the visible external pattern of the egg shell in Acutuncus and Notahypsibius gen. nov. makes it possible to suppose the same structure of the egg chorion for these two species. Ultrastructural investigations (Eibye-Jacobsen 1997; Poprawa 2011; Janelt et al. 2019) of egg development in Halobiotus crispae Kristensen, 1982, 
Grevenius granulifer (Thulin, 1928) and Thulinius ruffoi (Bertolani, 1982) revealed the presence of the distinct pillars connecting the inner and outer layers of the chorion in the species with the egg shell usually considered to be smooth. As a result, the only difference between the typical 'smooth' eggs of most of the Hypsibioidea and Isohypsibioidea and the eggs with visible pillars within the shell (Acutuncus, Notahypsibius gen. nov., H. roanensis and H. cf. scabropygus) is the degree of the pillars' development making them visible in LM. In my opinion, this trait could have often been omitted in older observations of the eggs of other species due to the insufficient quality of the optics and the prevailing opinion that eggs laid in the exuvium are always smooth. For example, a careful investigation of the eggs of Pilatobius recamieri revealed the presence of the same type structure of the egg chorion (Fig. $7 \mathrm{H}$ ).

The same structure of the egg shell was also described in Macrobiotidae Thulin, 1928 (Poprawa et al. 2015). Using the Transmission Electron Microscopy, the presence of the pillars connecting the outer and inner layers of the egg shell was revealed in Macrobiotus polonicus Pilato, Kaczmarek, Michalczyk \& Lisi, 2003. This species has a continuous external layer of the egg shell, while in other species of the Macrobiotus hufelandi group this layer is modified to a mesh-like structure, supported by the pillars (Fig. 10A-B, white arrowheads). It also seems that such internal pillars form the dot-like pattern often visible in LM between the egg processes in some species of Macrobiotidae. For example, eggs of Tenuibiotus voronkovi (Tumanov, 2006) have a distinct dot-like pattern visible in LM, between the processes bases (Fig. 10C, black arrowhead; not mentioned in the original description), while SEM shows the absence of any granulation on the egg surface (Fig. 10D).

In my opinion, the presence of egg shell pillars visible in LM should be considered as a state, poorly delimited from the completely smooth egg shell (with pillars visible in EM only), and clearly different from the presence of true ornamentation consisting of the external processes. The development of the external processes does not exclude the presence of the internal pillars-like structures in the shell, but often these structures undergo progressive development, forming a mesh-like system of trabecules denoted as the "labyrinthine layer" (Węglarska 1982; Poprawa 2005).

It should also be noted that some tardigrade species have eggs with large, protruding pillar-like structures in the shell enclosed within the thin outer membrane. Egg shells of this type are known within both Heterotardigrada Marcus, 1927 (Oreella Murray, 1910) and Eutardigrada (Macrobiotidae, Murrayidae Guidetti, Rebecchi \& Bertolani, 2000, Eohypsibiidae Bertolani \& Kristensen, 1987) (Bertolani et al. 1996; Dastych et al. 1998). In my opinion, this type of egg shell structure could be derived from the primitive three-layered shell as a result of the progressive development of the internal pillars. This hypothesis can explain the emergence of similar-looking structures in several phylogenetically distant groups and possibly can partially resolve the known paradox in the tardigrade systematics formulated by Guidetti et al. (2006): “...there are closely related species, which share a very similar morphology of the animals but clearly differ in their egg morphology. Conversely, there are species belonging to different evolutionary lines that have similar eggs, but very different adult morphology". Surely, wide comparative TEM investigation of the egg chorion of different tardigrade species is needed to check this hypothesis.

It is interesting to note that, while within Eohypsibiidae the type of the egg shell ornamentation is genusspecific (pillar-like structures in Eohypsibius Kristensen, 1982 and external processes with labyrinthine layer in Bertolanius Özdikmen, 2008 and Austeruseus Trygvadóttir \& Kristensen, 2011 (Trygvadóttir \& Kristensen 2011; Hansen et al. 2017)), in Macrobiotidae and Murrayidae two genera include species with both types of the egg shell - Murrayon Bertolani \& Pilato, 1988 and Minibiotus Schuster, 1980. The polyphyly of the genus Murrayon was previously demonstrated via molecular analyses (Bertolani et al. 2014; Guidetti et al. 2016). It incorporates at least two clades - one with the pillar-like structures 
of the egg shell (M. dianeae (Kristensen, 1982) and related) and the other with the external conical processes (M. pullari (Murray, 1907) and related). Unfortunately, no molecular data are available on the species M. ovoglabellus (Biserov, 1988), which is known to lay smooth eggs. The genus Minibiotus is also suspected to be polyphyletic (Guidetti et al. 2007; Bertolani et al. 2014; Stec et al. 2015), but new molecular data are needed to test this hypothesis.

\section{Bucco-pharyngeal apparatus of the Diphascon model}

In the revision of the genus Diphascon, Pilato (1987) accepted the hypothesis of several independent origins of the long buccal tube with a flexible caudal part within Hypsibiidae as the most likely. He considered as a less likely alternative, the hypothesis of the presence of an independent monophyletic group within Hypsibiidae with a Diphascon-like buccal tube, where the shape of the apophyses for the insertion of the stylet muscles became identical to that of some species with a rigid buccal tube.
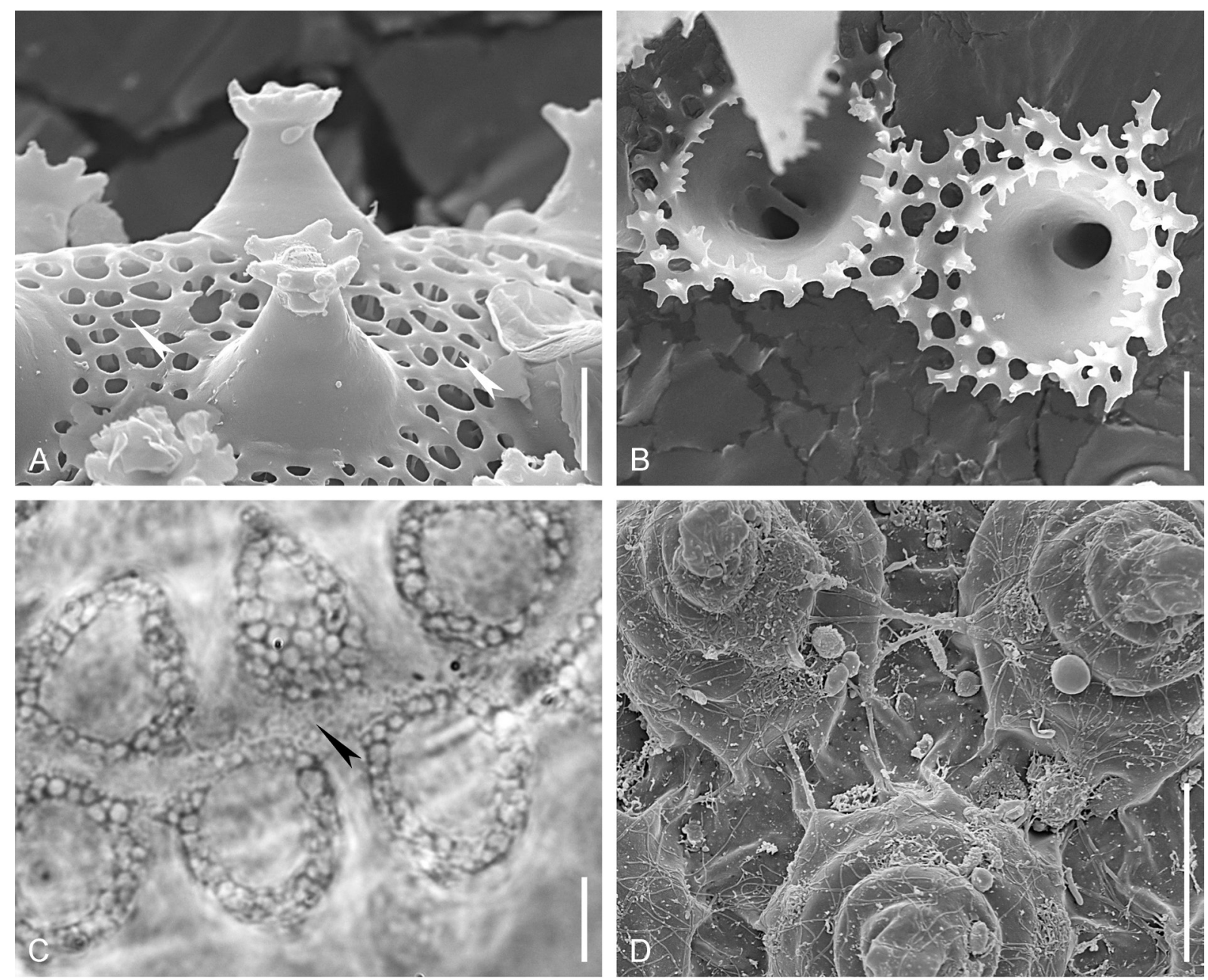

Fig. 10. Details of the egg shell structure in Macrobiotidae. A. Egg shell surface of Macrobiotus cf. sottilei Pilato, Kiosya, Lisi \& Sabella, 2012, white arrowheads indicate the internal pillars of the egg shell, SEM. B. Fragment of the outer shell layer of $M$. cf. sottilei egg visible from inside, with numerous pillars, deriving from the lower surface of the reticulated outer layer, SEM. C. Fragment of the egg surface of Tenuibiotus voronkovi (Tumanov, 2006) with granulation-like pattern visible between the egg processes (SPbU 205(4)), PhC. D. Fragment of the egg shell of $T$. voronkovi in SEM, note the absence of the surface granulation. Scale bars: $A-B=2 \mu \mathrm{m} ; C-D=5 \mu \mathrm{m}$. 
The presence of the bucco-pharyngeal apparatus of the Diphascon model within Macrobiotidae and Eohypsibiidae was considered as a confirmation of the possibility of the independent evolution of this trait. But after this work was published, a much wider distribution of the Diphascon-like buccal tube within Eutardigrada sensu lato (including the order Apochela Schuster, Nelson, Grigarick \& Christenberry, 1980) has been revealed. Now, it is also known in three of four genera of Milnesiidae Ramazzotti, 1962 (Dastych 2011) and in the possibly closely-related Carphania Binda, 1978 (Binda \& Kristensen 1986); in all major clades of Hypsibioidea: Ramazzottiidae, Diphasconinae, Itaquasconinae, and Pilatobiinae (Bertolani et al. 2014); in several genera of Macrobiotidae, possibly presenting different phylogenetic lines (Guidetti \& Pilato 2003); in one of three known genera of Eohypsibiidae (Kristensen 1982) and, possibly, in Isohypsibioidea, if Paradiphascon is treated as belonging to that order (Gąsiorek et al. 2019c). Consequently, a new hypothesis of the presence of the flexible pharyngeal tube as a plesiomorphy of the whole Eutardigrada sensu lato, was suggested by Bertolani et al. (2014). In my opinion, the position of the genus Notahypsibius gen. nov. on the obtained phylogram within the morphological genus Pilatobius can be considered as evidence of a possible reduction of the caudal flexible part of the buccal tube within the taxon with an initially Diphascon-like buccal tube (such a reduction was also recently hypothesized by Gąsiorek \& Michalczyk (2020) for the subfamilies Hypsibiinae and Itaquasconinae). As so, it strongly supports the hypothesis of the initially bipartite construction of the buccal tube within Eutardigrada sensu lato and independent reduction of the caudal flexible part in different phylogenetic lines.

\section{Phylogeny and taxonomy of Pilatobiinae}

The subfamily Pilatobiinae was established by Bertolani et al. (2014) when the phylogenetic analysis of $18 \mathrm{~S}$ and $28 \mathrm{~S}$ gene markers revealed that several species, previously attributed to the genus Diphascon (D. nodulosum, D. patanei and D. ramazzottii) form a separate clade within Hypsibiidae. These species, together with morphologically similar species of the genus Diphascon, were moved to a newly established genus Pilatobius. Morphological diagnosis of the subfamily Pilatobiinae, given by Bertolani et al. (2014), was based on the characters of the genus Pilatobius as it was the only genus within this clade at that time.

The phylogenetic analysis shown herein involved two additional Pilatobius species (P. recamieri and P. islandicus) with recently obtained gene sequences (Gąsiorek et al. 2017; Buda et al. 2018). The presence of the separate clade forming the subfamily Pilatobiinae was confirmed, but the analysis showed that the genus Notahypsibius gen. nov. was positioned within this clade and, moreover, within the genus Pilatobius. In this situation, the subfamily Pilatobiinae is still valid in terms of being a wellsupported clade, but in lack of a suitable morphological diagnosis. No morphological characters can be pinpointed as an autapomorphy of this taxon. The only character possibly shared by Notahypsibius gen. nov. and Pilatobius is the presence of the pillars of the egg shell, visible in LM (known only for one species of Pilatobius), but this trait should not be considered significant because it is known to be present in other species of the family Hypsibiidae, belonging to the different clades.

The genus Pilatobius appears to be paraphyletic, as it consists of the monophyletic clade P. islandicus / P. recamieri/P. patanei/N. pallidoides and two species (P. nodulosus and P. ramazzottii) being sister to this species complex. Taking into account the small number of species of the genus Pilatobius with known gene sequences available for inclusion in the phylogenetic analysis (5 of 26 species), I prefer not to change the taxonomical status of this genus, and instead leave it with the diagnosis given to Pilatobiinae by Bertolani et al. (2014) with the following redaction: "Genus Pilatobius Bertolani et al. 2014. Buccal tube followed by an annulated pharyngeal tube, with a drop-like thickening between them; pharyngeal bulb roundish or slightly oval, always containing 2 macroplacoids similar in length and in rows that look as parentheses, and a septulum. Claws of the Hypsibius type." 


\section{Acknowledgements}

I thank Professor Giovanni Pilato and Professor Oscar Lisi (University of Catania, Italy) for giving me the possibility to examine microscope slides from Binda \& Pilato's collection and for the discussion of my results. I thank Dr Roberta Salmaso and Dr Leonardo Latella (curators of the tardigrade collections of the Museum of Natural History of Verona, Italy) as well as Professor Roberto Guidetti and Professor Roberto Bertolani (University of Modena and Reggio Emilia, Italy), who let me examine microscope slides from the collections of W. Maucci and for sending additional photos of $H$. scaber. I am grateful to Dr Yevgen Kiosya (School of Biology, V.N. Karazin Kharkiv National University, Ukraine) for sending me the slides of type series of $H$. pallidoides. I thank Professor Torbjørn Ekrem (Norwegian University of Science and Technology) for providing me the unpublished DNA extraction protocol. I extend my thanks to my friend Prof. Alexey Smirnov (Saint-Petersburg State University, Russia) for collecting material in Austria and for his constant support and advise in the molecular part of my investigation. I thank Erica DeMilio (National University of Ireland Galway, Republic of Ireland) for the linguistic review of the manuscript. This study was carried out with the use of equipment of the Core Facilities Centers "Culture Collection of Microorganisms", "Centre for Molecular and Cell Technologies" and "Centre for Microscopy and Microanalysis" of St Petersburg State University.

\section{References}

Bartels P.J., Apodaca J.J., Mora C. \& Nelson D.R. 2016. A global biodiversity estimate of a poorly known taxon: phylum Tardigrada. Zoological Journal of the Linnean Society 178 (4): 730-736. https://doi.org/10.1111/zoj.12441

Beasley C.W., Kaczmarek Ł. \& Michalczyk Ł. 2008. Doryphoribius mexicanus, a new species of Tardigrada (Eutardigrada: Hypsibiidae) from Mexico (North America). Proceedings of the Biological Society of Washington 121 (1): 34-40. https://doi.org/10.2988/07-30.1

Bertolani R., Rebecchi L. \& Claxton S.K. 1996. Phylogenetic significance of egg shell variation in tardigrades. Zoological Journal of the Linnean Society 116 (1-2): 139-148.

https://doi.org/10.1111/j.1096-3642.1996.tb02339.x

Bertolani R., Biserov V., Rebecchi L. \& Cesari M. 2011a. Taxonomy and biogeography of tardigrades using an integrated approach: new results on species of the Macrobiotus hufelandi group. Invertebrate Zoology 8 (1): 23-36. https://doi.org/10.15298/invertzool.08.1.05

Bertolani R., Rebecchi L., Giovannini I. \& Cesari M. 2011b. DNA barcoding and integrative taxonomy of Macrobiotus hufelandi C.A.S. Schultze 1834, the first tardigrade species to be described, and some related species. Zootaxa 2997 (1): 19-36. https://doi.org/10.11646/zootaxa.2997.1.2

Bertolani R., Guidetti R., Marchioro T., Altiero T., Rebecchi L. \& Cesari M. 2014. Phylogeny of Eutardigrada: new molecular data and their morphological support lead to the identification of new evolutionary lineages. Molecular Phylogenetics and Evolution 76: 110-126.

https://doi.org/10.1016/j.ympev.2014.03.006

Binda M.G. \& Kristensen R.M. 1986. Notes on the genus Oreella (Oreellidae) and the systematic position of Carphania fluviatilis Binda, 1978. (Carphaniidae fam. nov., Heterotardigrada). Animalia 13 (1/3): 9-20.

Binda M.G. \& Pilato G. 1986. Ramazzottius, nuova genere di Eutardigrado (Hypsibiidae). Animalia 13 (1/3): 159-166.

Buda J., Olszanowski Z., Wierzgoń M. \& Zawierucha K. 2018. Tardigrades and oribatid mites in bryophytes from geothermally active lava fields (Krafla, Iceland) and the description of Pilatobius islandicus sp. nov. (Eutardigrada). Polish Polar Research 39 (3): 425-453. https://doi.org/10.24425/118755 
Cesari M., Vecchi M., Palmer A., Bertolani R., Pilato G., Rebecchi L. \& Guidetti R. 2016. What if the claws are reduced? Morphological and molecular phylogenetic relationships of the genus Haplomacrobiotus May, 1948 (Eutardigrada, Parachela). Zoological Journal of the Linnean Society 178 (4): 819-827. https://doi.org/10.1111/zoj.12424

Cohen B.L. 2018. Match and mismatch of morphological and molecular phylogenies: causes, implications, and new light on cladistics. Zoological Journal of the Linnean Society 184 (2): 516-527. https://doi.org/10.1093/zoolinnean/zly004

Dabert M., Dastych H., Hohberg K. \& Dabert J. 2014. Phylogenetic position of the enigmatic clawless eutardigrade genus Apodibius Dastych, 1983 (Tardigrada), based on 18S and 28S rRNA sequence data from its type species A. confusus. Molecular Phylogenetics and Evolution 70: 70-75.

https://doi.org/10.1016/j.ympev.2013.09.012

Darriba D., Taboada G.L., Doallo R. \& Posada D. 2012. jModelTest 2: more models, new heuristics and parallel computing. Nature Methods 9 (8): 772. https://doi.org/10.1038/nmeth.2109

Dastych H. 1984. The Tardigrada from Antarctic with descriptions of several new species. Acta Zoologica Cracoviensia 27 (19): 377-436.

Dastych H. 1988. The Tardigrada of Poland. Wyd. 1. Państwowe Wydawn. Nauk, Warszawa.

Dastych H. 1991. Redescription of Hypsibius antarcticus (Richters, 1904), with some notes on Hypsibius arcticus (Murray, 1907) (Tardigrada). Mitteilungen aus dem Hamburgischen Zoologischen Museum und Institut 88: 141-159.

Dastych H. 2009. Thalerius konradi gen. nov., sp. nov., a new tardigrade from the periglacial area of the Ötztal Alps, Austria (Tardigrada). Contributions to Natural History (12): 391-402.

Dastych H. 2011. Bergtrollus dzimbowski gen. n., sp. n., a remarkable new tardigrade genus and species from the nival zone of the Lyngen Alps, Norway (Tardigrada: Milnesiidae). Entomologische Mitteilungen aus dem Zoologischen Museum Hamburg 15 (186): 335-359.

Dastych H. 2018. Redescription and revalidation of the sub-antarctic tardigrade Hypsibius murrayi (Richters, 1907) based on the rediscovered type material (Tardigrada, Panarthropoda). Entomologie heute 30: 95-115.

Dastych H. 2019. Cryobiotus roswithae gen. n., sp. n., a new genus and species of glacier-dwelling tardigrades from Northern Norway (Tardigrada, Panarthropoda). Entomologie heute 31: 95-111.

Dastych H., McInnes S.J. \& Claxton S.K. 1998. Oreella mollis Murray, 1910 (Tardigrada): a redescription and revision of Oreella. Mitteilungen aus dem Hamburgischen Zoologischen Museum und Institut 95: $89-113$.

Degma P., Bertolani R. \& Guidetti R. 2019. Actual checklist of Tardigrada. $36^{\text {th }}$ Edition: 1-09-2019. https://doi.org/10.25431/11380_1178608

Edgar R.C. 2004. MUSCLE: multiple sequence alignment with high accuracy and high throughput. Nucleic Acids Research 32 (5): 1792-1797. https://doi.org/10.1093/nar/gkh340

Eibye-Jacobsen J. 1997. New observations on the embryology of the Tardigrada. Zoologischer Anzeiger 235: 201-216.

Eibye-Jacobsen J. 2001. A new method for making SEM preparations of the tardigrade buccopharyngeal apparatus. Zoologischer Anzeiger 240 (3-4): 309-319.

https://doi.org/10.1078/0044-5231-00038 
Folmer O., Black M., Hoeh W., Lutz R. \& Vrijenhoek R. 1994. DNA primers for amplification of mitochondrial cytochrome c oxidase subunit I from diverse metazoan invertebrates. Molecular Marine Biology and Biotechnology 3 (5): 294-299.

Gąsiorek P. \& Michalczyk Ł. 2020. Phylogeny of Itaquasconinae in the light of the evolution of the flexible pharyngeal tube in Tardigrada. Zoologica Scripta 49 (4): 499-515. https://doi.org/10.1111/zsc.12424

Gąsiorek P., Stec D., Morek W., Zawierucha K., Kaczmarek Ł., Lachowska-Cierlik D. \& Michalczyk Ł. 2016. An integrative revision of Mesocrista Pilato, 1987 (Tardigrada: Eutardigrada: Hypsibiidae). Journal of Natural History 50 (45-46): 2803-2828.

https://doi.org/10.1080/00222933.2016.1234654

Gąsiorek P., Zawierucha K., Stec D. \& Michalczyk Ł. 2017. Integrative redescription of a common Arctic water bear Pilatobius recamieri (Richters, 1911). Polar Biology 40 (11): 2239-2252.

https://doi.org/10.1007/s00300-017-2137-9

Gąsiorek P., Stec D., Morek W. \& Michalczyk Ł. 2018. An integrative redescription of Hypsibius dujardini (Doyère, 1840), the nominal taxon for Hypsibioidea (Tardigrada: Eutardigrada). Zootaxa 4415 (1): 45. https://doi.org/10.11646/zootaxa.4415.1.2

Gąsiorek P., Morek W., Stec D., Blagden B. \& Michalczyk Ł. 2019a. Revisiting Calohypsibiidae and Microhypsibiidae: Fractonotus Pilato, 1998 and its phylogenetic position within Isohypsibiidae (Eutardigrada: Parachela). Zoosystema 41 (1): 71-89.

https://doi.org/10.5252/zoosystema2019v41a6

Gąsiorek P., Morek W., Stec D. \& Michalczyk Ł. 2019b. Untangling the Echiniscus Gordian knot: paraphyly of the "arctomys group" (Heterotardigrada: Echiniscidae). Cladistics 35: 633-653.

https://doi.org/10.1111/cla.12377

Gąsiorek P., Stec D., Morek W. \& MichalczykŁ. 2019c. Deceptive conservatism of claws: distinct phyletic lineages concealed within Isohypsibioidea (Eutardigrada) revealed by molecular and morphological evidence. Contributions to Zoology 88 (1): 78-132. https://doi.org/10.1163/18759866-20191350

Gouy M., Guindon S. \& Gascuel O. 2010. SeaView version 4: a multiplatform graphical user interface for sequence alignment and phylogenetic tree building. Molecular Biology and Evolution 27 (2): 221224. https://doi.org/10.1093/molbev/msp259

Guidetti R. \& Bertolani R. 2001. The tardigrades of Emilia (Italy). III. Piane di Mocogno (Northern Apennines). Zoologischer Anzeiger 240 (3): 377-383. https://doi.org/10.1078/0044-5231-00045

Guidetti R. \& Pilato G. 2003. Revision of the genus Pseudodiphascon (Tardigrada, Macrobiotidae), with the erection of three new genera. Journal of Natural History 37 (14): 1679-1690.

https://doi.org/10.1080/00222930210126659

Guidetti R., Nelson D.R. \& Bertolani R. 1999. Ecological and faunistic studies on tardigrades in leaf litter of beach forests. Zoologischer Anzeiger 238: 215-223.

Guidetti R., Altiero T. \& Hansen J.G. 2006. A new species of freshwater tardigrades from Disko Island (Greenland) increases an unsolved paradox in tardigrade systematics. Hydrobiologia 558 (1): 69-79. https://doi.org/10.1007/s10750-005-1408-6

Guidetti R., Bertolani R. \& Degma P. 2007. New taxonomic position of several Macrobiotus species (Eutardigrada: Macrobiotidae). Zootaxa 1471: 61-68. https://doi.org/10.11646/zootaxa.1471.1.6

Guidetti R., Schill R.O., Bertolani R., Dandekar T. \& Wolf M. 2009. New molecular data for tardigrade phylogeny, with the erection of Paramacrobiotus gen. nov. Journal of Zoological Systematics and Evolutionary Research 47 (4): 315-321. https://doi.org/10.1111/j.1439-0469.2009.00526.x 
Guidetti R., Rebecchi L., Bertolani R., Jönsson K.I., Kristensen R.M. \& Cesari M. 2016. Morphological and molecular analyses on Richtersius (Eutardigrada) diversity reveal its new systematic position and lead to the establishment of a new genus and a new family within Macrobiotoidea. Zoological Journal of the Linnean Society 178 (4): 834-845. https://doi.org/10.1111/zoj.12428

Guidetti R., Cesari M., Bertolani R., Altiero T. \& Rebecchi L. 2019a. High diversity in species, reproductive modes and distribution within the Paramacrobiotus richtersi complex (Eutardigrada, Macrobiotidae). Zoological Letters 5 (1): 1. https://doi.org/10.1186/s40851-018-0113-Z

Guidetti R., Massa E., Bertolani R., Rebecchi L. \& Cesari M. 2019b. Increasing knowledge of Antarctic biodiversity: new endemic taxa of tardigrades (Eutardigrada; Ramazzottiidae) and their evolutionary relationships. Systematics and Biodiversity 17: 573-593.

https://doi.org/10.1080/14772000.2019.1649737

Guil N. \& Giribet G. 2012. A comprehensive molecular phylogeny of tardigrades-adding genes and taxa to a poorly resolved phylum-level phylogeny. Cladistics 28 (1): 21-49.

https://doi.org/10.1111/j.1096-0031.2011.00364.x

Guil N., Machordom A. \& Guidetti R. 2013. High level of phenotypic homoplasy amongst eutardigrades (Tardigrada) based on morphological and total evidence phylogenetic analyses. Zoological Journal of the Linnean Society 169 (1): 1-26. https://doi.org/10.1111/zoj.12046

Guil N., Jørgensen A. \& Kristensen R. 2019. An upgraded comprehensive multilocus phylogeny of the Tardigrada tree of life. Zoologica Scripta 48 (1): 120-137. https://doi.org/10.1111/zsc.12321

Hansen J.G., Kristensen R.M., Bertolani R. \& Guidetti R. 2017. Comparative analyses of Bertolanius species (Eohypsibiidae; Eutardigrada) with the description of Bertolanius birnae sp. nov. from northern polar regions. Polar Biology 40 (1): 123-140. https://doi.org/10.1007/s00300-016-1931-0

Hedges S.B. \& Sibley C.G. 1994. Molecules vs. morphology in avian evolution: the case of the "pelecaniform" birds. Proceedings of the National Academy of Sciences of the United States of America 91 (21): 9861-9865. https://doi.org/10.1073/pnas.91.21.9861

Hillis D.M. 1987. Molecular versus morphological approaches to systematics. Annual Review of Ecology and Systematics 18 (1): 23-42. https://doi.org/10.1146/annurev.es.18.110187.000323

Horning D.S.J., Schuster R.O. \& Grigarick A.A. 1978. Tardigrada of New Zealand. New Zealand Journal of Zoology 5 (2): 185-280. https://doi.org/10.1080/03014223.1978.10428316

Janelt K., Jezierska M. \& Poprawa I. 2019. The female reproductive system and oogenesis in Thulinius ruffoi (Tardigrada, Eutardigrada, Isohypsibiidae). Arthropod Structure \& Development 50: 53-63.

https://doi.org/10.1016/j.asd.2019.04.003

Jørgensen A., Faurby S., Hansen J.G., Møbjerg N. \& Kristensen R.M. 2010. Molecular phylogeny of Arthrotardigrada (Tardigrada). Molecular Phylogenetics and Evolution 54 (3): 1006-1015.

https://doi.org/10.1016/j.ympev.2009.10.006

Jørgensen A., Møbjerg N. \& Kristensen R.M. 2011. Phylogeny and evolution of the Echiniscidae (Echiniscoidea, Tardigrada) - an investigation of the congruence between molecules and morphology Journal of Zoological Systematics and Evolutionary Research 49: 6-16.

https://doi.org/10.1111/j.1439-0469.2010.00592.x

Kaczmarek Ł. \& Michalczyk Ł. 2017. The Macrobiotus hufelandi group (Tardigrada) revisited. Zootaxa 4363 (1): 101. https://doi.org/10.11646/zootaxa.4363.1.4

Kaczmarek Ł., Zawierucha K., Buda J., Stec D., Gawlak M., Michalczyk Ł. \& Roszkowska M. 2018. An integrative redescription of the nominal taxon for the Mesobiotus harmsworthi group (Tardigrada: 
Macrobiotidae) leads to descriptions of two new Mesobiotus species from Arctic. PLoS ONE 13 (10): e0204756. https://doi.org/10.1371/journal.pone.0204756

Kiehl E., Dastych H., D'Haese J. \& Greveh H. 2007. The 18S rDNA sequences support polyphyly of the Hypsibiidae (Eutardigrada). Journal of Limnology 66 (Suppl. 1): 21-25.

https://doi.org/10.4081/jlimnol.2007.s1.21

Kosztyła P., Stec D., Morek W., Gąsiorek P., Zawierucha K., Michno K., Ufir K., Małek D., Hlebowicz K., Laska A., Dudziak M., Frohme M., Prokop Z.M., Kaczmarek Ł. \& Michalczyk Ł. 2016. Experimental taxonomy confirms the environmental stability of morphometric traits in a taxonomically challenging group of microinvertebrates. Zoological Journal of the Linnean Society 178: 765-775.

https://doi.org/10.1111/zoj.12409

Kristensen R.M. 1982. New aberrant Eutardigrades from homothermic springs on Disko Island, West Greenland. In: Nelson D.R. (ed.) Proceedings of the Third International Symposium on the Tardigrada, August 3-6, 1980, Johnson City, Tennessee, USA: 203-220. East Tennessee State University Press, Johnson City, Tenn., USA.

Kumar S., Stecher G. \& Tamura K. 2016. MEGA7: Molecular Evolutionary Genetics Analysis version 7.0 for bigger datasets. Molecular Biology and Evolution 33 (7): 1870-1874.

https://doi.org/10.1093/molbev/msw054

Lisi O. 2015. Current knowledge on the Sicilian tardigrade fauna. Biodiversity Journal 6 (1): 297-304.

Marcus E. 1929. Tardigrada. Akademische Verlagsgesellschaft m.b.H, Leipzig.

Marcus E. 1930. Beiträge zur Tardigradensystematik. Zoologische Jahrbücher Abteilung für Systematik, Ökologie und Geographie der Tiere 59: 363-386

Marcus E. 1936. Tardigrada. Walter de Gruyter \& Co., Berlin/Leipzig.

Marley N.J., Mcinnes S.J. \& Sands C.J. 2011. Phylum Tardigrada: a re-evaluation of the Parachela. Zootaxa 2819 (1): 51. https://doi.org/10.11646/zootaxa.2819.1.2

Maucci W. 1987. A contribution to the knowledge of the North American Tardigrada with emphasis on the fauna of Yellowstone National Park (Wyoming). In: Bertolani R. (ed.) Biology of Tardigrades: Proceedings of the $4^{\text {th }}$ International Symposium on the Tardigrada, Modena, September 3-5, 1985: 187-210. Mucchi, Modena.

Maucci W. 1988. Tardigrada from Patagonia (Southern South America) with description of three new species. Revista Chilena de Entomología 16: 5-13.

Maucci W. 1996. Tardigrada of the Arctic tundra with descriptions of two new species. Zoological Journal of the Linnean Society 116 (1-2): 185-204. https://doi.org/10.1111/j.1096-3642.1996.tb02343.x

Michalczyk Ł. \& Kaczmarek Ł. 2013. The Tardigrada Register: a comprehensive online data repository for tardigrade taxonomy. Journal of Limnology 72 (1s): e22. https://doi.org/10.4081/jlimnol.2013.s1.e22

Miller M.A., Pfeiffer W. \& Schwartz T. 2010. Creating the CIPRES Science Gateway for inference of large phylogenetic trees. In: 2010 Gateway Computing Environments Workshop (GCE): 1-8.

Morek W., Stec D., Gąsiorek P., Schill R.O., Kaczmarek Ł. \& Michalczyk Ł. 2016. An experimental test of eutardigrade preparation methods for light microscopy. Zoological Journal of the Linnean Society 178 (4): 785-793. https://doi.org/10.1111/zoj.12457

Murray J. 1907a. Scottish Tardigrada collected by the Lake Survey. Transactions of the Royal Society of Edinburgh 45 (3): 641-668. https://doi.org/10.1017/S0080456800011777 
Murray J. 1907b. Arctic Tardigrada, collected by Wm. S. Bruce. Transactions of the Royal Society of Edinburgh 45 (3): 669-681. https://doi.org/10.1017/S0080456800011789

Osawa S., Su Z.-H. \& Imura Y. 2004. Molecular Phylogeny and Evolution of Carabid Ground Beetles. Springer Japan, Tokyo.

Pilato G. 1969. Evoluzione e nuova sistemazione degli eutardigrada. Bolletino di Zoologia 36 (3): $327-$ 345. https://doi.org/10.1080/11250006909436925

Pilato G. 1981. Analisi di nuovi caratteri nello studio degli Eutardigradi. Animalia 8 (1/3): 51-57.

Pilato G. 1987. Revision of the genus Diphascon Plate, 1889, with remarks on the subfamily Itaquasconinae (Eutardigrada, Hypsibiidae). In: Bertolani R. (ed.) Biology of Tardigrades: Proceedings of the $4^{\text {th }}$ International Symposium on the Tardigrada, Modena, September 3-5, 1985: 337-357. Mucchi, Modena.

Pilato G. 1992. Mixibius, nuovo genere di Hypsibiidae (Eutardigrada). Animalia 19 (1/3): 121-125.

Pilato G. \& Binda M.G. 1990. Tardigradi dell Antartide. I. Ramajendas, nuovo genere di Eutardigrado. Nuova posizione sistematica di Hypsibius renaudi Ramazzotti, 1972 e descrizione di Ramajendas frigidus n. sp. Animalia 17: 61-71.

Pilato G. \& Binda M.G. 1997. Acutuncus, a new genus of Hypsibiidae (Eutardigrada). Entomologische Mitteilungen aus dem Zoologischen Museum Hamburg 12 (155): 159-162.

Pilato G. \& Binda M.G. 2010. Definition of families, subfamilies, genera and subgenera of the Eutardigrada, and keys to their identification. Zootaxa 2404 (1): 1. https://doi.org/10.11646/zootaxa.2404.1.1

Pilato G., Binda M.G. \& Claxton S. 2002. Itaquascon unguiculum and Itaquascon cambewarrense. two new species of eutardigrades from Australia. New Zealand Journal of Zoology 29 (2): 87-93.

https://doi.org/10.1080/03014223.2002.9518293

Pilato G., Binda M.G. \& Lisi O. 2003. Remarks on some species of tardigrades from South America with the description of Minibiotus sidereus n. sp. Zootaxa 195: 1-8. https://doi.org/10.11646/zootaxa.195.1.1

Pilato G., Kiosya Y., Lisi O., Inshina V. \& Biserov V. 2011. Annotated list of Tardigrada records from Ukraine with the description of three new species. Zootaxa 3123 (1): 1-31.

https://doi.org/10.11646/zootaxa.3123.1.1

Pilato G., Kiosya Y., Lisi O. \& Sabella G. 2012. New records of Eutardigrada from Belarus with the description of three new species. Zootaxa 3179: 39-60. https://doi.org/10.11646/zootaxa.3179.1.2

Pleijel F., Jondelius U., Norlinder E., Nygren A., Oxelman B., Schander C., Sundberg P. \& Thollesson M. 2008. Phylogenies without roots? A plea for the use of vouchers in molecular phylogenetic studies. Molecular Phylogenetics and Evolution 48 (1): 369-371. https://doi.org/10.1016/j.ympev.2008.03.024

Poprawa I. 2005. The structure and the formation of egg shells in the parthenogenetic species Dactylobiotus dispar Murray, 1907 (Tardigrada: Eutardigrada). Folia Biologica 53 (3): 173-177. https://doi.org/10.3409/173491605775142828

Poprawa I. 2011. Ultrastructural studies of the formation of the egg capsule in the hermaphroditic species, Isohypsibius granulifer granulifer Thulin, 1928 (Eutardigrada: Hypsibiidae). Zoological Science 28 (1): 37-40. https://doi.org/10.2108/zsj.28.37

Poprawa I., Schlechte-Wełnicz W. \& Hyra M. 2015. Ovary organization and oogenesis in the tardigrade Macrobiotus polonicus Pilato, Kaczmarek, Michalczyk \& Lisi, 2003 (Eutardigrada, Macrobiotidae): ultrastructural and histochemical analysis. Protoplasma 252 (3): 857-865.

https://doi.org/10.1007/s00709-014-0725-x 
Ramazzotti G. \& Maucci W. 1983. Il phylum Tardigrada. Istituto Italiano di Idrobiologia, Verbania Pallanza.

Richters F. 1911. Faune des mousses. Tardigrades. Duc d'Orleans, Campagne arctique de 1907. Imprimerie Scientifique C. Belens, Bruxelles.

Ronquist F. \& Huelsenbeck J.P. 2003. MrBayes 3: Bayesian phylogenetic inference under mixed models. Bioinformatics 19 (12): 1572-1574. https://doi.org/10.1093/bioinformatics/btg180

Sands C.J., McInnes S.J., Marley N.J., Goodall-Copestake W.P., Convey P. \& Linse K. 2008. Phylum Tardigrada: an "individual" approach. Cladistics 24 (6): 861-871.

https://doi.org/10.1111/j.1096-0031.2008.00219.x

Schuster R.O., Nelson D.R., Grigarick A.A. \& Christenberry D. 1980. Systematic criteria of the Eutardigrada. Transactions of the American Microscopical Society 99 (3): 284. https://doi.org/10.2307/3226004

Scotland R.W., Olmstead R.G. \& Bennett J.R. 2003. Phylogeny reconstruction: the role of morphology. Systematic Biology 52 (4): 539-548.

Smirnov A., Nassonova E., Berney C., Fahrni J., Bolivar I. \& Pawlowski J. 2005. Molecular phylogeny and classification of the lobose amoebae. Protist 156 (2): 129-142.

https://doi.org/10.1016/j.protis.2005.06.002

Smith N.D. \& Turner A.H. 2005. Morphology's role in phylogeny reconstruction: perspectives from paleontology. Systematic Biology 54 (1): 166-173. https://doi.org/10.1080/10635150590906000

Stamatakis A. 2014. RAxML version 8: a tool for phylogenetic analysis and post-analysis of large phylogenies. Bioinformatics 30 (9): 1312-1313. https://doi.org/10.1093/bioinformatics/btu033

Stec D., Smolak R., Kaczmarek Ł. \& Michalczyk Ł. 2015. An integrative description of Macrobiotus paulinae sp. nov. (Tardigrada: Eutardigrada: Macrobiotidae: hufelandi group) from Kenya. Zootaxa 4052: 501-526. https://doi.org/10.11646/zootaxa.4052.5.1

Stec D., Gąsiorek P., Morek W., Kosztyła P., Zawierucha K., Michno K., Kaczmarek Ł., Prokop Z.M. \& Michalczyk Ł. 2016a. Estimating optimal sample size for tardigrade morphometry. Zoological Journal of the Linnean Society 178 (4): 776-784. https://doi.org/10.1111/zoj.12404

Stec D., Morek W., Gąsiorek P., Kaczmarek Ł., \& Michalczyk Ł. 2016b. Determinants and taxonomic consequences of extreme egg shell variability in Ramazzottius subanomalus (Biserov, 1985) (Tardigrada). Zootaxa 4208 (2): 176-188. https://doi.org/10.11646/zootaxa.4208.2.5

Stec D., Morek W., Gąsiorek P. \& Michalczyk Ł. 2018. Unmasking hidden species diversity within the Ramazzottius oberhaeuseri complex, with an integrative redescription of the nominal species for the family Ramazzottiidae (Tardigrada: Eutardigrada: Parachela). Systematics and Biodiversity 16 (4): 357-376. https://doi.org/10.1080/14772000.2018.1424267

Thulin G. 1911. Beiträge zur Kenntnis der Tardigradenfauna Schwedens. Arkiv för zoologi 7: 1-60. https://doi.org/10.5962/bhl.part.1270

Trygvadóttir B.V. \& Kristensen R.M. 2011. Eohypsibiidae (Eutardigrada, Tardigrada) from the Faroe Islands with the description of a new genus containing three new species. Zootaxa 2886: 39-62. https://doi.org/10.11646/zootaxa.2886.1.4

Tumanov D.V. 1997. Hypsibius iskandarovi sp. n., a new species of Tardigrada from fresh waters of North-West Russia (Tardigrada: Hypsibiidae). Zoosystematica Rossica 5 (2): 219-220.

Tumanov D.V. 2018. Hypsibius vaskelae, a new species of Tardigrada (Eutardigrada, Hypsibiidae) from Russia. Zootaxa 4399 (3): 434. https://doi.org/10.11646/zootaxa.4399.3.12 
Vecchi M., Cesari M., Bertolani R., Jönsson K.I., Rebecchi L. \& Guidetti R. 2016. Integrative systematic studies on tardigrades from Antarctica identify new genera and new species within Macrobiotoidea and Echiniscoidea. Invertebrate Systematics 30 (4): 303. https://doi.org/10.1071/IS15033

Velasco-Castrillón A., McInnes S.J., Schultz M.B., Arróniz-Crespo M., D’Haese C.A., Gibson J.A.E., Adams B.J., Page T.J., Austin A.D., Cooper S.J.B. \& Stevens M.I. 2015. Mitochondrial DNA analyses reveal widespread tardigrade diversity in Antarctica. Invertebrate Systematics 29 (6): 578-590.

https://doi.org/10.1071/IS14019

Węglarska B. 1982. Ultrastructural study of the formation of egg envelopes in Macrobiotus richtersi (Eutardigrada). In: Nelson D.R. (ed.) Proceedings of the Third International Symposium on the Tardigrada, August 3-6, 1980, Johnson City, Tennessee, USA: 115-127. East Tennessee State University Press, Johnson City, Tenn., USA.

Wiens J.J. 2004. The role of morphological data in phylogeny reconstruction. Systematic Biology 53 (4): 653-661. https://doi.org/10.1080/10635150490472959

Zantke J., Wolff C. \& Scholtz G. 2008. Three-dimensional reconstruction of the central nervous system of Macrobiotus hufelandi (Eutardigrada, Parachela): implications for the phylogenetic position of Tardigrada. Zoomorphology 127 (1): 21-36. https://doi.org/10.1007/s00435-007-0045-1

Zawierucha K., Stec D., Lachowska-Cierlik D., Takeuchi N., Li Z. \& Michalczyk Ł. 2018. High mitochondrial diversity in a new water bear species (Tardigrada: Eutardigrada) from mountain glaciers in Central Asia, with the erection of a new genus Cryoconicus. Annales Zoologici 68 (1): 179-201.

https://doi.org/10.3161/00034541ANZ2018.68.1.007

Manuscript received: 23 January 2020

Manuscript accepted: 22 May 2020

Published on: 7 July 2020

Topic editor: Rudy Jocqué

Desk editor: Pepe Fernández

Printed versions of all papers are also deposited in the libraries of the institutes that are members of the EJT consortium: Muséum national d'histoire naturelle, Paris, France; Meise Botanic Garden, Belgium; Royal Museum for Central Africa, Tervuren, Belgium; Royal Belgian Institute of Natural Sciences, Brussels, Belgium; Natural History Museum of Denmark, Copenhagen, Denmark; Naturalis Biodiversity Center, Leiden, the Netherlands; Museo Nacional de Ciencias Naturales-CSIC, Madrid, Spain; Real Jardín Botánico de Madrid CSIC, Spain; Zoological Research Museum Alexander Koenig, Bonn, Germany; National Museum, Prague, Czech Republic.

\section{Supplementary files}

SM.01. Complete list of species analyzed, with their GenBank accession numbers.

SM.02. The phylogeny of Hypsibioidea based on concatenated 18S $+28 \mathrm{~S}$ sequences.

SM.03. Uncorrected pairwise distances. 